\title{
The Sam Houston Home, 41WA46, Huntsville, Walker County, Texas: 1980-1981 Archeological Investigations and Monitoring
}

Jody C. Pevey

Prewitt and Associates, Inc.

Follow this and additional works at: https://scholarworks.sfasu.edu/ita

Part of the American Material Culture Commons, Archaeological Anthropology Commons, Environmental Studies Commons, Other American Studies Commons, Other Arts and Humanities Commons, Other History of Art, Architecture, and Archaeology Commons, and the United States History Commons

Tell us how this article helped you.

This Article is brought to you for free and open access by the Center for Regional Heritage Research at SFA ScholarWorks. It has been accepted for inclusion in Index of Texas Archaeology: Open Access Gray Literature from the Lone Star State by an authorized editor of SFA ScholarWorks. For more information, please contact cdsscholarworks@sfasu.edu. 


\section{The Sam Houston Home, 41WA46, Huntsville, Walker County, Texas: 1980-1981 Archeological Investigations and Monitoring}

\section{Creative Commons License}

\section{(c) (i) $\Theta($}

This work is licensed under a Creative Commons Attribution-NonCommercial-No Derivative Works 4.0 International License. 
THE SAM HOUSTON HOME, 41WA46, HUNTSVILLE, WALKER COUNTY, TEXAS: 1980-1981

ARCHEOLOGICAL INVESTIGATIONS

AND MONITORING

by

Jody C. Pevey

PRINCIPAL INVESTIGATOR: Elton R. Prewitt

REPORTS OF INVESTIGATIONS, NUMBER 12

Prewitt and Associates, Inc.

Consulting Archeologists

Austin, Texas

February 1981 
Report submitted to Sam Houston Memorial Museum, Sam Houston State University, Huntsville, Texas, by Prewitt and Associates, Inc. in fulfillment of the terms of Purchase Order No. 1-2396-118648. These investigations were conducted under the terms of Antiquities Permit No. 258 issued by the Texas Antiquities Committee, Austin, Texas, on 13 August 1980. 


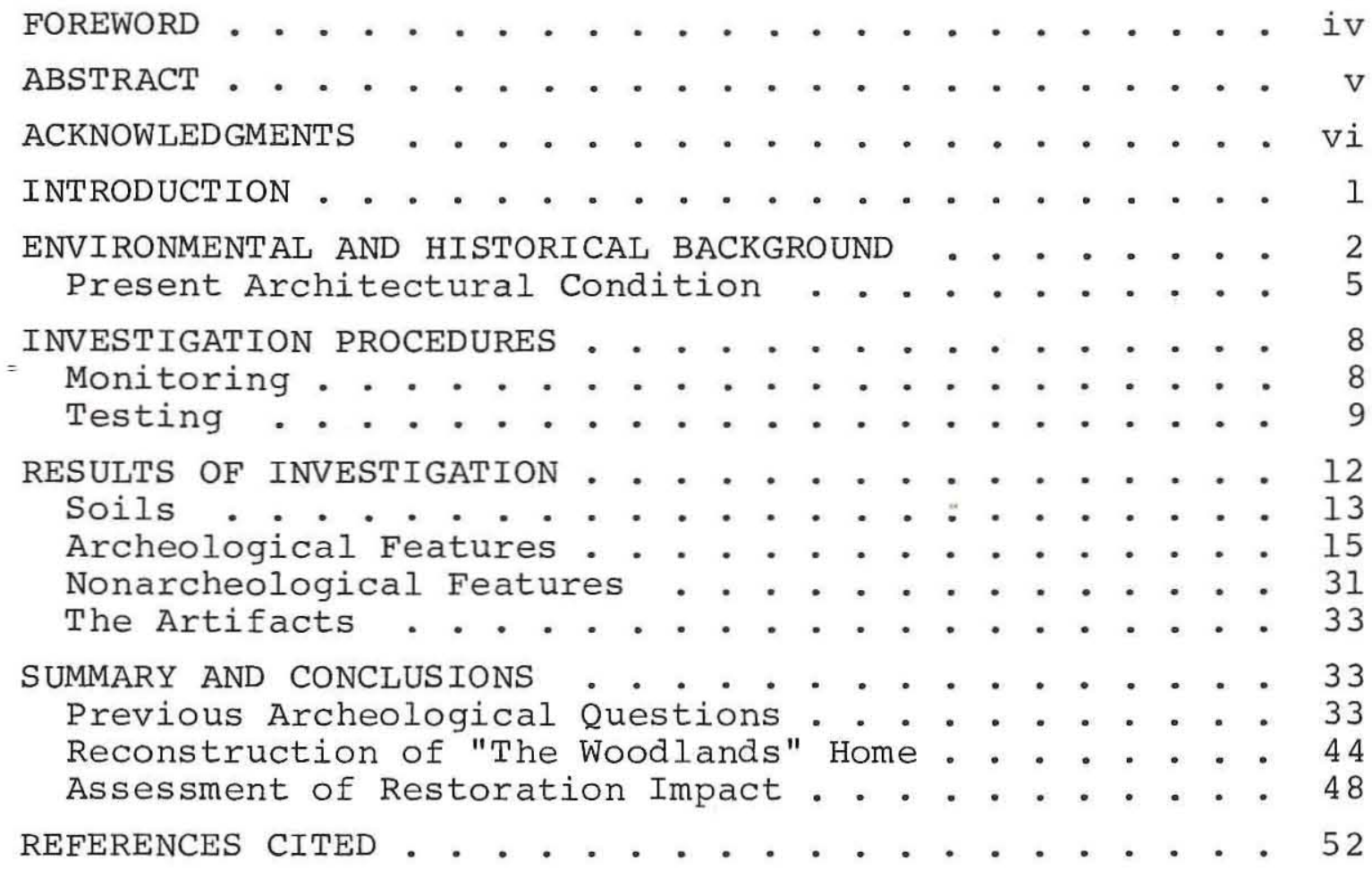

\section{LIST OF FIGURES}

1. Site location map . . . . . . . . . . . . . 3

2. General site photographs . . . . . . . . . . 7

3. Site plan map . . . . . . . . . . . . . . . 21

4. General excavation photographs . . . . . . . . . 25

5. Original brick chimney pad photographs . . . . . . 29

6. House alignments . . . . . . . . . . ! . 45

\section{LIST OF TABLES}

1. The archeological features . . . . . . . . . . 17

2. Testing provenience chart . . . . . . . . . . . 34

3. Trench 1 artifact provenience . . . . . . . . . 41

4. Monitoring, Test Pit 55 . . . . . . . . . . . . . 41

5. Monitoring provenience chart . . . . . . . . . . 42

6. Metric data for house .. . . . . . . . . . 46

7. Metric data for rear porch . . . . . . . . . 49 
FOREWORD

Additional archeological investigations and monitoring of restoration activities at the Sam Houston Home in Huntsville, Texas, are described in this report prepared by Jody C. Pevey. The original location of the Law Office was not found, but significant features relating to the Houston Home were discovered. Removal of the existing east chimney and pad revealed the remnants of an earlier brick chimney pad with associated brick hearth supports. The types of bricks, mortar and construction techniques appear to be the same as those noted in a series of exterior and interior brick piers found along the south side of the house.

The features are interpreted to represent one or two events associated with the original building episode. The positioning of the piers and chimney pad suggest the present house location is very close to the original position, and that the original rear porch was about 3.6 meters (12 feet) wide. A thorough study of nail hole patterns on the house is needed to test this interpretation, and we suggest this be done before restoration activities result in yet another set of square nail holes which will only add to the confusion currently surrounding the original appearance of the Houston Home.

Ms. Pevey has done an excellent job in preparing a concise report of the archeological findings at "The Woodlands." We feel it contributes to the resolution of some of the controversies surrounding the much-needed restoration of the Houston Home and Law Office.

Elton R. Prewitt Principal Investigator 
ABSTRACT

Archeological testing and monitoring activities conducted from November 1980 to January 1981 at site 41WA46, the Sam Houston Home, "The Woodlands," and the Sam Houston Law Office in Huntsvizze, Walker County, Texas, yielded new documentation concerning the positioning of the existing house relative to its original location. When combined with the data reported in Prewitt and Associates, Inc. Reports of Investigations, Number 4, regarding the original house location, the data accumulated during the present testing program provide convincing evidence of close agreement between the existing structure placement and the original location. A chimney foundation and several interior and exterior support piers, all constructed of hand-molded low temperature fired bricks, are interpreted to be the remains associated with either a single construction episode or a closely spaced series of construction episodes. While it is not possible to pinpoint a specific date for the construction episode(s), it is certain that the event(s) took place between 1847 and 1878 when $S$. Smedes purchased the property. The positioning of the brick piers suggests the original rear porch extended the length of the south face of the house; further, the width of the porch was found to be 3.6 meters (approximately 12 feet). Excavations in and around the Law office failed to yield evidence of the original location of that structure; however, intact nineteenth century midden deposits are contained within the fill under the Law office. 


\section{ACKNOWLEDGMENTS}

Restoration requires information from a number of different sources, including historical, architectural and special research, as well as archeological investigation.

Thanks are extended to several people for their patient assistance, cooperation and advice during monitoring and testing at "The Woodlands." Mr. Curtis Morris, Mr. Luther Lasky and the staff of the Sam Houston Memorial Museum; Mr. Cyrus Jones of Bell, Klein and Hoffman, Architects, Austin, Texas; and Mr. Tyrus Cox, Mr. Clairent Bont Hopkins and the crew of Cox Construction Company, Fredericksburg, Texas.

Finally, I would like to express my appreciation to the personnel of Prewitt and Associates, Inc.: Jan A. Guy and Laura H. Trawick, the archeological crew, who were thoroughly professional in their work and contributed mental and physical endurance in both the field and laboratory; Linda Nance for typing the report and cataloguing the photographs; Steven M. Kotter for advice and editing; Sandra Hannum and Kerza A. Prewitt for their skilled drafting and report production; Susan Andrews for laboratory assistance; and Margaret Howard for help in cataloguing artifacts. Particular thanks go to the Principal Investigator, Elton R. Prewitt, who provided the time, counsel and patience essential to this type of investigation. I would also like to thank the State Archeologist, Mr. Curtis Tunnell, for his helpful visits to the site.

The altruism displayed by all these people during the course of this project is respected and appreciated. 


\section{INTRODUCTION}

Archeological investigations at the Sam Houston Home, "The Woodlands," in Huntsville, Walker County, Texas, were conducted by Prewitt and Associates, Inc. from November 1980 through January 1981. Sponsored by the Sam Houston State University, Huntsville, Texas, the work was done in conjunction with restoration of Sam Houston's home, "The Woodlands," and an associated structure commonly known as Houston's "Law Office" (Fig. 1). Restoration work is being done by Cox Construction Company of Fredericksburg, Texas, in conformance with restoration plans developed by Bell, Klein and Hoffman, restoration architects, of Austin, Texas. The archeological work accomplished under the present contract agreement conforms to the provisions of state of Texas Antiquities Permit No. 258; the Principal Investigator was Elton R. Prewitt and fieldwork was supervised by Jody Pevey, Project Archeologist.

The current investigations at the Sam Houston Home consist of two separate categories of work:

(1) monitoring of the architectural restoration of the house structure and law office; and

(2) additional subsurface archeological excavations in previously defined sensitive areas which are expected to be directly impacted by the restoration activities.

The latter category of investigations also addresses two of the questions which provided the basis for the original work done at the site by Clark (1980: 1-2).

(1) Was the house returned to its original site in 1911?

(2) What was the nature of the original chimney(s)? Excavations at the Houston Home during the current season were concentrated in the area formerly covered by the rear porch. Several units were placed to coincide as 
closely as possible with the trenches necessary for new foundation footings since these are the areas to be directly impacted by subsurface restoration activities. Other units were placed to provide additional data on several brick architectural features located by clark in 1979.

Investigations within the Law Office were directed toward insuring that restoration activities will not adversely affect any intact nineteenth century midden deposits or subsurface features.

\section{ENVIRONMENTAL AND HISTORICAL BACKGROUND}

A review of the environmental and historical background and the architectural and construction history for the Sam Houston Home has been presented by Clark (1980: 6-23) and will not be repeated here. A summary of the major events concerning "The Woodlands" from the Houstonera occupation between 1847 and 1853 to the return of the house to the original site during the early twentieth century and the current restoration is given below in order to provide a general background for the discussions of the results of the present investigations (Clark 1980: 21-23).

1847 Construction of house, kitchen, law office, latrine, servant house and possibly other outbuildings

1853- Houston's occupation ends. Negotiations with 1855 William M. Leach for Sam Houston to sell the property taking Leach's notes of indebtedness in payment. Houston periodically occupying home. In April 1855, full property ownership reverted back to Houston because Leach never paid the notes. 


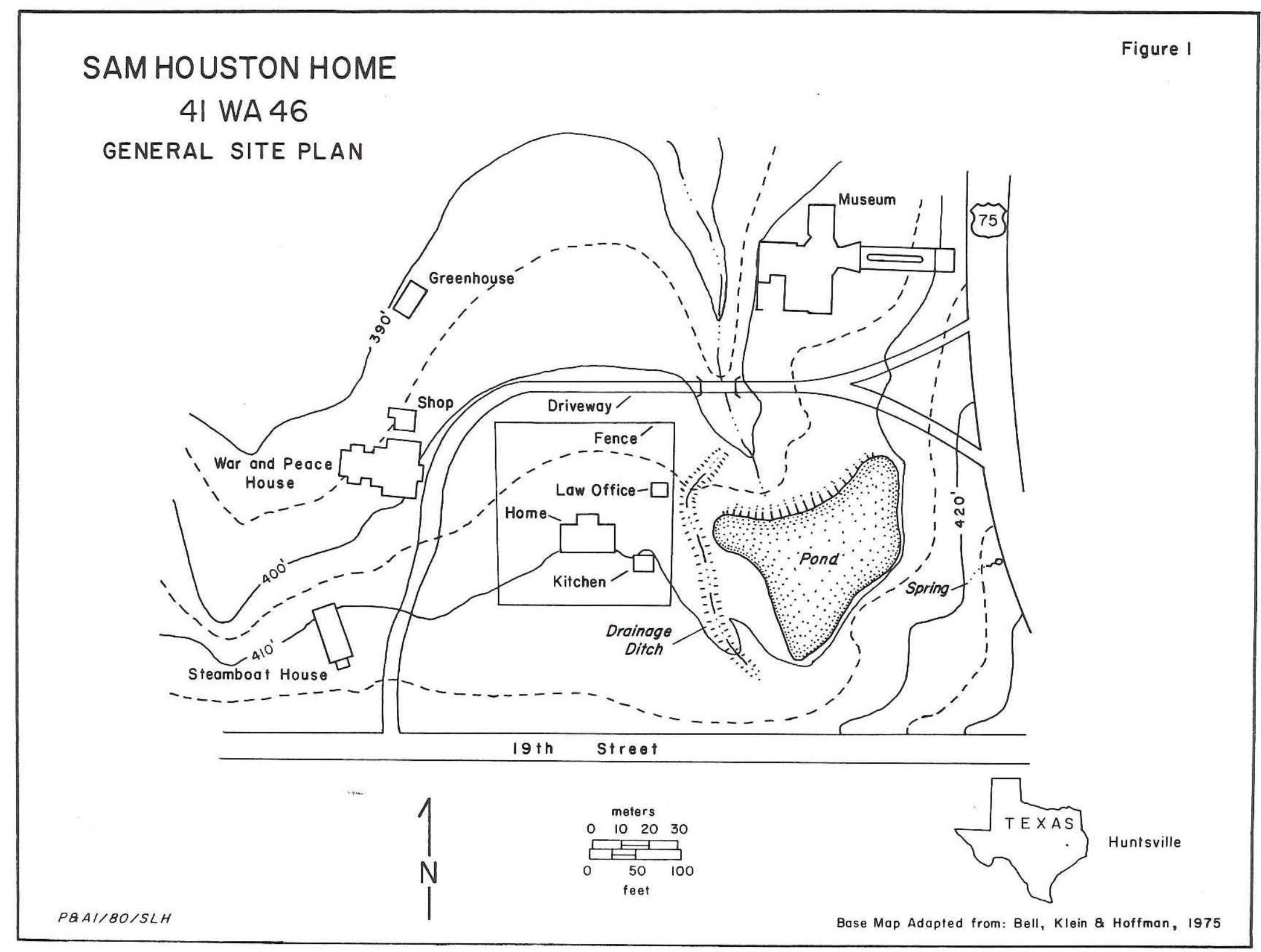


1857 Property sold to J. Carroll Smith

1862 Property sold to J.W. Bush

1876 Property sold to W. T. House

1878 S. Smedes' purchase of property; conversion to boarding house for female students.

ca. Siding on house first horizontal then board and

1880 batten on rear.

1880- East additions built using both wire and cut

1895 nails; gabled portico present on house.

1901 Law Office moved off property

1905 House moved off property

1911 Fire at house; house returned to site; ell not moved but shed rear porch moved; new roof; gabled portico present; stovepipes in roof; no chimneys; second floor hall closed; no shutters present; new contrasting color paint; rear door in west room not present.

1914- Brick chimney built on each end; rear porch 1924 enclosed with windows; grounds landscaped when subject to Department of Agriculture of Sam Houston State University activities.

1925 Fire; erosion of grounds; no chimney on west end; stovepipe visible.

1927- Gabled portico removed; second floor hall

1929 reopened; rear additions built; stone chimneys built on east and west ends and on east end of rear addition; new interior wall boards; new floor joists and flooring in west upstairs room.

1930- Stone chimneys on house removed and replaced with 1936 brick; probable removal of chimney on east addition; removal of stone yard fence to be replaced by a picket fence; considerable landscaping. 
1956- Gabled portico rebuilt; wooden shutters added; spring 1960 covered; pond expanded.

1960- Air conditioning added; interior board and batten

1978 siding placed in rooms with insulation; gas line added; sprinkler system added; electrical lines added; pond cleaned, dammed, and channel dug on west side of pond; filling of yard.

1979 Archeological investigations in May, September and October by James E. Corbin of Stephen F. Austin State University and by Prewitt and Associates, Inc. Installation of burglar alarm line from northeast corner of yard to southeast corner of front porch.

1980 Restoration efforts begin in June on Sam Houston Home and the Law Office. Extensive reconstruction and stabilization. Archeological monitoring and additional investigations in November and December by Prewitt and Associates, Inc.

Present Architectural Condition

In the intervening time between the 1979 and the 1980 excavations, considerable changes occurred in and around the Sam Houston Home. Restoration activities on the house and the Law office which were directed toward "putting [them] back as nearly as possible into the form [they] held at a particular date or period in time" (Bullock 1966: 1) began in June 1980.

The status of restoration on the Sam Houston Home at the time of the 1980 testing is as follows:

(1) the house proper has been raised and placed on pine supports which coincide indirectly with the exposed 1929 cement foundation piers (Fig. $2 a$ and $b$ );

(2) the Neo-Classic porch which was rebuilt in 1956-1960 and the 1927-1936 rear additions have been removed; 
Figure 2. General Site Photographs

a. Sam Houston Home, October 1979, looking southwest, before restoration activities.

b. Sam Houston Home, November 1980, looking southwest, in-progress restoration activities. 
Figure 2
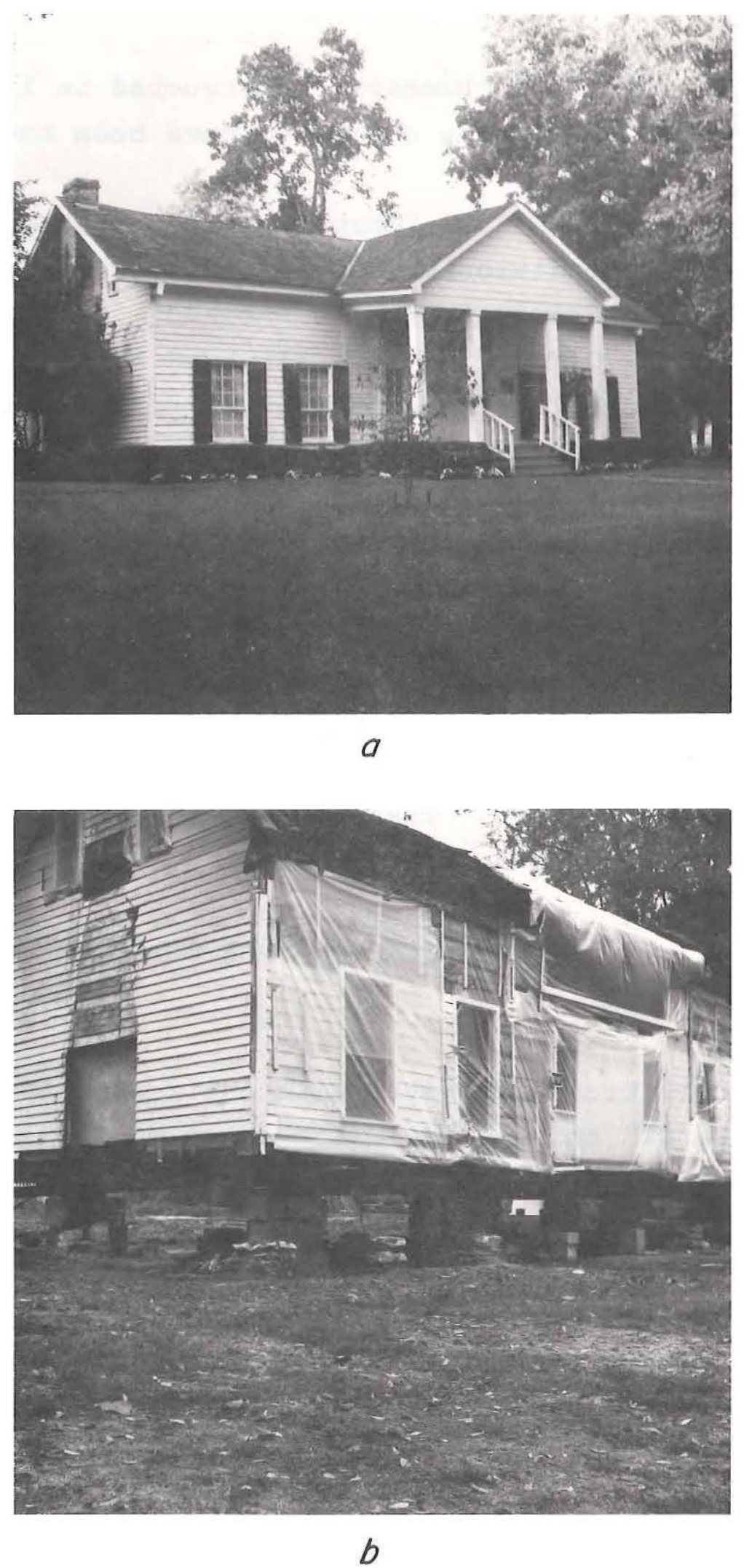
(3) the brick chimneys, constructed in 1930-1936 to replace the 1929 stone chimneys, have been torn down; and

(4) all 1960-1978 improvements to the house, such as central air conditioning, sprinkler system and gas lines have either been removed or disconnected.

The Law Office has been elevated and is resting on wooden beams. Four concrete corner pier footings, 61x61 centimeters in area and 24-30 centimeters in thickness, have been constructed; 22 cubic yards of compacted fill has been introduced to stabilize the structure foundation; and the twentieth century east wall chimney has been removed.

The area surrounding the Sam Houston Home has not been significantly disrupted although the site has been minimally disturbed by the construction of a hurricane fence surrounding the perimeter of the house, the Law Office and the kitchen. There are to be no restoration activities conducted on the kitchen.

\section{INVESTIGATION PROCEDURES}

\section{Monitoring}

Activities associated with the restoration of "The Woodlands" and the Law Office were monitored to ensure that construction components of the original structures and the subsurface features previously identified as potentially dating to the Houston occupation (1847-1853) were not impacted. Monitoring included periodic inspections of all materials removed from the house structure during restoration as well as on-site observation of the removal and reinstallation of the 
foundation piers. Notes were taken to describe the monitoring activities and any artifacts recovered at this time were placed in appropriately labeled provenience bags and included in the Artifact Description section of this report.

Monitoring activities resulted in the identification of five features associated with construction prior to the Smedes occupation beginning in 1878. A brick chimney pad (Feature 9) was discovered following the removal of a later (1930-1936) concrete pad; this precipitated the excavation of Test Pit 53 and the recording of Features 9, 10 and 14 . The two latter features are brick hearth supports. Features 15 and 16 are exterior porch piers which were encountered during the excavation of Test Pits 54 and 55.

$\underline{\text { Testing }}$

The present testing program includes two phases of investigation. Test units excavated during the initial phase conducted on November 21 and 22, 1980, demonstrated the need for additional testing which was subsequently accomplished from December 1 through December 5, 1980. The testing program included:

(1) Test Pit 46 placed within the interior of the Law Office to determine the presence of any architectural subsurface features or intact nineteenth century midden deposits;

(2) Test Pits 47, 48, 49, 51 and 52 placed in the area to be directly impacted by support structures (concrete beam pier) for the rear porch addition;

(3) Test Pit 50 placed to further define a subsurface architectural feature located in Test Pit 48; and (4) Test Pits 53, 54 and 55 associated with monitoring activities. 
All test units were $1 \times 2$ meters in size except for Test Pit 53 which was expanded to $2 \times 3$ meters to completely record Feature 9, Test Pit 54 which was excavated specifically to fully expose Feature 15 and was $1.5 \times 1$ meter in size, and Test Pit 55 which was $1 \times 1$ meter and was excavated on the premise that Feature 16 would be encountered at that location. Test units were numbered by continuing Clark's 1979 sequence which ended with Test Pit 45.

The placement of the test units within the existing site grid was determined by re-establishing clark's east-west base line and setting stakes at measured points along this line in the area of the rear porch which had been removed from the house; two stakes were set north of this line within the interior of the Law Office. Additional stakes were also placed along and north of the main east-west base line for the test units excavated during monitoring. After two corners of a test unit were established, the right triangle-hypotenuse method was employed to place the remaining corner stakes.

All test units were oriented with their long axis either grid north/south or east/west. The orientation of Test Pits 46 (N/S), 47 (E/W), 48 (E/W) and 49 (N/S) was determined arbitrarily; Test Pits 50 (N/S), $51(\mathrm{E} / \mathrm{W}), 52(\mathrm{E} / \mathrm{W}), 53(\mathrm{~N} / \mathrm{S}), 54(\mathrm{E} / \mathrm{W})$ and 55 were strategically oriented to record architectural features.

The vertical provenience of each unit was established from Elevation Datum No. 2 (Temporary Benchmark in Fig. 3), elevation 125.354 meters (411.267 feet) above mean sea level (MSL); this datum consists of a length of concrete reinforcement rod driven into the ground at a point $60 \mathrm{~cm}$ north of the southwest corner of the 
kitchen and 40 centimeters west of the west wall of the kitchen. Elevation Datum No. 2 is a temporary benchmark which was established by utilizing a USGS survey marker which had been set in 1935 when the City of Huntsville conducted a topographic survey for city water resource planning. The USGS benchmark, which is labeled "SAM \#1," is located " 0.2 miles west along 19th St., 141 feet west of the center line of the driveway leading North into Sam Houston Park; 28 feet north of the center line of 19 th Street; 1 foot north of a stone wall" (Murray Moore Surveyors 1935: 19). A brass cap was set in concrete with an elevation of 127.307 meters (417.427 feet) above MSL. Fill was removed in arbitrary 20-centimeter increments; vertical measurements were taken from the ground surface of the southeast stake with the aid of a line level. All ten test pits were excavated to a depth of at least 40 centimeters below the ground surface. Basal clay was encountered at a depth of 45-50 centimeters below ground surface in the Law office and between 55-60 centimeters below ground surface in the area of the removed rear porch of the house.

The matrix from each of the test units excavated (except Test Pits 54 and 55) was dry-screened through $\frac{1}{4}-$ inch mesh hardware cloth; all cultural materials recovered were placed in artifact bags appropriately labeled for horizontal and vertical provenience. The matrix removed from Test Pits 54 and 55 was not screened although several nineteenth century artifacts were recovered from the units during excavation. The artifacts collected from in and around Feature 16 (between 30 and 40 centimeters below ground surface) were placed in a general provenience bag. 
The documentation of each unit included an excavation record (level notes), plan drawings of the bottom of each level to include any features and/or anomalies, at least one profile drawing, photographs, sketches and conjectural remarks by the excavator. A daily log, a feature log and a photographic log were kept; also maintained were tabulations of all elevations and a map on which was indicated the excavation unit placement, the grid system and the location of Elevation Datum No. 2.

\section{RESULTS OF INVESTIGATION}

Ten test units were excavated in or adjacent to the area previously covered by the rear porch of the Sam Houston Home and within the Law Office during the present investigations.

The results of these test units substantiate Clark's findings of extensive disturbance at the site. An average of 40 centimeters of easily recognizable disturbed fill mixed with rubble was noted within the area previously covered by the rear porch of the house. This area was disturbed as a result of activities associated with the removal of the Home from the site in 1905 and $^{i}$ several subsequent construction episodes between 1911, when the Home was returned to its present location, and 1936. The interior of the Law Office has been disturbed to a lesser degree than the house structure and surrounding areas because the only construction activity associated with this structure was the addition of the east wall chimney.

The density of mid-to-late-nineteenth century artifacts recovered from the removed rear porch of the 
house was noticeably less than the densities noted by Clark for adjacent areas along the south side of the porch. This paucity of cultural materials, especially those dating from the Houston-era occupation of the site, can be attributed to the positioning of the rear additions to the house. As a rule, the greatest quantity of artifacts accumulate along and just under the edge of a porch; this distribution pattern correlates precisely with the data obtained during the 1979 and 1980-81 seasons of work at the Houston Home.

The eight test units placed in and adjacent to the area of the removed rear porch and the unit placed along the east wall of the house revealed structural remains which pre-date the Smedes occupation of the site beginning in 1878. As revealed in Clark (1980) the majority of the structural remains linked to the Smedes additions exhibited a crude design comprised of sandstone and cement components. The structural components identified include six intact brick foundation piers, a brick feature which probably represents a displaced foundation pier, an intact brick chimney pad and two interior brick hearth supports associated with the chimney pad. Although not conclusively demonstrated by the present investigation, it seems likely that all other structural remains associated with these brick features may have been previously destroyed or disturbed by early twentieth century restoration activities.

$\underline{\text { Soils }}$

Clark (1980: 28-29) recognized four distinct soil zones during the 1979 testing program. The stratigraphically lowest deposit recognized was a very dense yellow to 
yellow-orange sandy clay. Overlying this is a deposit of light tan sandy loam, genetically derived from the clay, which varies in thickness from 0-35 centimeters and averages about 20 centimeters. This deposit appears to be thinnest at the southwest corner of the house and thickest northeast of the house. Above these natural deposits is a medium to dark brown sandy loam containing numerous artifacts and which is interpreted as being an undisturbed occupation midden. This zone, which averages 15 centimeters in thickness, was noted only around the major structures. The final and uppermost soil zone is a medium brown sandy loam mixed by plowing and disturbed by landscaping and other modern impacts; this zone averages 30-35 centimeters in thickness.

Observations made during the present testing and monitoring program agree substantially with Clark's soil descriptions. All test units contained evidence of the midden zone; however, the organically stained cultural zone yielded low numbers of artifacts; few of the artifacts are datable to the mid-nineteenth century Houston occupation. The midden zone, which varies between 33-40 centimeters below ground surface, probably dates from the early twentieth century and is contemporaneous with or possibly post-dates the return of the house to its original location in 1911.

The light brown sandy loam deposit above the midden zone varies greatly in thickness; it extends from the ground surface to 40 centimeters in Test Pit 52, 15 centimeters in Test Pit 46 and 20 centimeters in Test Pit 53. In profile this zone appears to be highly disturbed and mixed with brick and rubble fill. In Test Pits 
48 and 52 the upper 10 centimeters of this zone contained a basal clay cap.

Two soil anomalies were noted during excavation. Thin lenses of sandy wash alternating with normal upper zone soil lenses were observed in profile in Test Pit 50 , the northernmost unit excavated in the area of the removed rear porch. This anomaly apparently resulted from sheet erosion of sandy fill brought in for the purpose of landscaping the sloping ground on the south side of the house. In Test Pits 49 and 53 a dramatic thinning of the midden zone, the second major soil anomaly, was noted.

The ground surface existing at the time of the 1980 testing program exhibits an approximately 20-degree northward slope which has resulted from past activities at the site; in particular, ground surface modifications prior to the construction of the existing brick sidewalk and considerable landscaping appear to be responsible for this slope. Overall it is safe to say that there is an average of 20-25 centimeters of disturbed recent fill overlying any nineteenth-century or Houston-era materials and features.

Archeological Features

A total of fourteen additional archeological features and several nonarcheological features were recorded during the present excavations. These features are discussed using categories and terminology taken from Clark (1980) for consistency of data and for the correlation of the features with previous investigations. The archeological features recorded during the current work, summarized in Table 1, are divided into the following categories: 
(1) Brick foundation piers;

(2) Concrete foundation piers;

(3) Brick chimney foundations;

(4) Concrete chimney foundations;

(5) Brick hearth supports;

(6) Post molds; and

(7) Pits.

These features date primarily from the Houston through the Smedes occupations of the site although some are obviously related to twentieth century activities.

Nonarcheological features include natural disturbances and modern (1960-1978) improvements and constructions relating to the use of the Houston Home as a part of the existing museum complex.

\section{Brick Foundation Piers}

Four nineteenth century brick foundation piers were recorded which, with the four brick piers encountered during the 1979 excavations, form the structural components of the apparent original rear porch foundation. The remains of two intact piers (Features 3 and 15), one collapsed pier (Feature 16) and the rubble remnants of another displaced brick pier (Feature 4) were recorded in Test Pits 48, 54, 55 and 51 respectively. All features are composed of "hand-molded low temperature fired brick which exhibit a paste of red-brown sandy clay" (Clark 1980: 43) .

The intact pier in Test Pit 48 is approximately 35-40 centimeters square and comprised of eight bricks averaging $20 \times 10 \times 5$ centimeters in size. In profile, two full courses are evident; the two courses combined average 10-15 centimeters in height. The characteristics of 
TABLE 1

THE ARCHEOLOGICAL FEATURES

\begin{tabular}{|c|c|c|c|c|}
\hline Feature \# & Provenience & Size & Description & Remarks \\
\hline 1 & $\begin{array}{l}\text { T.P. } 47 \\
\text { C.P. } N 30 / W 70 \text { * cm }\end{array}$ & $20 \times 25 \times 69 \mathrm{~cm}$ & $\begin{array}{l}\text { Cylindrical post mold containing } \\
\text { grey-brown sandy clay loam with } \\
\text { some basal clay mottling. }\end{array}$ & $\begin{array}{l}\text { Indeterminate function; } \\
\text { possible turn-of-the- } \\
\text { century fenceline; } \\
\text { early-to-mid-twentieth } \\
\text { century. }\end{array}$ \\
\hline 2 & $\begin{array}{l}\text { T.P. } 49 \\
\text { C.P. } \mathrm{N} 155 / \text { W95 cm }\end{array}$ & $14 \times 19 \times 20 \mathrm{~cm}$ & $\begin{array}{l}\text { Cylindrical post mold containing } \\
\text { pine wood fragments and grey- } \\
\text { brown sandy clay loam fill. }\end{array}$ & $\begin{array}{l}\text { Indeterminate function; } \\
\text { early-to-mid-twentieth } \\
\text { century. }\end{array}$ \\
\hline 3 & $\begin{array}{l}\text { T.P. } 48 \\
\text { C.P. } N 78 / W 55 \mathrm{~cm}\end{array}$ & $\begin{array}{l}40 \times 30 \mathrm{~cm} \\
\text { Each brick: ** } \\
20 \times 10 \times 05 \mathrm{~cm}\end{array}$ & $\begin{array}{l}\text { Intact brick foundation pier; hand- } \\
\text { molded bricks; three courses; } \\
\text { west interior. }\end{array}$ & $\begin{array}{l}\text { Probable interior rear } \\
\text { porch support; Houston } \\
\text { era - } 1878 .\end{array}$ \\
\hline 4 & $\begin{array}{l}\text { T.P. } 51 \\
\text { C.P. N } 90 / \mathrm{W} 80 \mathrm{~cm}\end{array}$ & & $\begin{array}{l}\text { Brick fragment scatter; possible } \\
\text { brick foundation pier; seven hand- } \\
\text { molded brick fragments; traces of } \\
\text { sandy lime mortar bonding on } \\
\text { fragments; east interior. }\end{array}$ & $\begin{array}{l}\text { Probable displaced } \\
\text { interior rear porch } \\
\text { support; Houston era - } \\
\text { 1878. }\end{array}$ \\
\hline 6 & $\begin{array}{l}\text { T.P. } 50 \\
\text { C.P. } N 85 / \mathrm{W} 5 \mathrm{~cm}\end{array}$ & $17 \times 20 \times 25 \mathrm{~cm}$ & $\begin{array}{l}\text { Cylindrical post mold containing } \\
\text { grey-brown sandy loam mottled } \\
\text { with dark brown and light tan } \\
\text { inclusions. }\end{array}$ & $\begin{array}{l}\text { Indeterminate function; } \\
\text { early-to-mid-twentieth } \\
\text { century. }\end{array}$ \\
\hline
\end{tabular}

${ }^{*}$ C.P. $=$ Center Point measured from southeast corner stake.

**A11 brick features are comprised of hand-molded, low temperature fired bricks. Each ful1-size brick averages $20 \times 10 \times 5 \mathrm{~cm}$. 
TABLE 1, Continued.

\begin{tabular}{|c|c|c|c|c|}
\hline Feature \# & Provenience & Size & Description & Remarks \\
\hline 7 & $\begin{array}{l}\text { T.P. } 50 \\
\text { C.P. } N 55 / \mathrm{W} 5 \mathrm{~cm}\end{array}$ & $12 \times 8 \times 16 \mathrm{~cm}$ & $\begin{array}{l}\text { Square post mold containing grey- } \\
\text { brown sandy loam mottled with dark } \\
\text { brown and light tan sandy loam } \\
\text { inclusions. }\end{array}$ & $\begin{array}{l}\text { Indeterminate function; } \\
\text { early-to-mid-twentieth } \\
\text { century. }\end{array}$ \\
\hline 8 & $\begin{array}{l}\text { T.P. } 50 \\
\text { C.P. } \mathrm{N} 45 / \mathrm{W} 40 \mathrm{~cm}\end{array}$ & $40 \times 20 \mathrm{~cm}$ & $\begin{array}{l}\text { Large square post mold containing } \\
\text { grey-brown sandy loam. }\end{array}$ & $\begin{array}{l}\text { Indeterminate function; } \\
\text { early-to-mid-twentieth } \\
\text { century. }\end{array}$ \\
\hline 10 & $\begin{array}{l}\text { T.P. } 53 \\
\text { C.P. } \mathrm{N} 262 / \mathrm{W} 210 \mathrm{~cm}\end{array}$ & & $\begin{array}{l}\text { Brick fragment scatter; hand- } \\
\text { molded bricks; some coursework } \\
\text { ( } 2 \text { courses); distinguishable } \\
\text { traces of bonding element. }\end{array}$ & $\begin{array}{l}\text { Probably north interior } \\
\text { hearth balance/support; } \\
\text { Houston era - } 1878 \text {. }\end{array}$ \\
\hline $12 * \star \star$ & $\begin{array}{l}\text { T.P. } 49 \\
\text { T.P. } 33 \text { (1979) }\end{array}$ & $40 \mathrm{~cm}$ square & $\begin{array}{l}\text { Brick foundation pier; hand-molded } \\
\text { bricks; two courses; southwest } \\
\text { corner (exterior). }\end{array}$ & $\begin{array}{l}\text { Probable exterior rear } \\
\text { porch support; Houston } \\
\text { era - } 1878 .\end{array}$ \\
\hline $13 * * *$ & $\begin{array}{l}\text { Trench } 1 \\
\text { T.P. } 22 \text { (1979) }\end{array}$ & $40 \mathrm{~cm}$ square & $\begin{array}{l}\text { Brick foundation pier; hand-molded } \\
\text { bricks; three courses; southeast } \\
\text { corner (exterior). }\end{array}$ & $\begin{array}{l}\text { Probable exterior rear } \\
\text { porch support; Houston } \\
\text { era - } 1878 \text {. }\end{array}$ \\
\hline 14 & T.P. 53 & $\begin{array}{l}\text { Approx. } 30-40 \\
\mathrm{~cm} \text { square }\end{array}$ & $\begin{array}{l}\text { Brick support pier; disturbed hand- } \\
\text { molded bricks; two evident courses; } \\
\text { traces of sandy lime mortar. }\end{array}$ & $\begin{array}{l}\text { Probable south interior } \\
\text { hearth balance/support; } \\
\text { Houston era - } 1878 \text {. }\end{array}$ \\
\hline
\end{tabular}

***Features encountered in 1979 investigations; Features 12, 13 and 18 were re-exposed in 1980. 
TABLE 1, Continued.

\begin{tabular}{|c|c|c|c|c|}
\hline Feature \# & Provenience & Size & Description & Remarks \\
\hline 15 & $\begin{array}{l}\text { T.P. } 54 \\
\text { T.P. } 39(1979) \\
\text { C.P. } \mathrm{N} 60 / \text { W } 110 \mathrm{~cm}\end{array}$ & $\begin{array}{l}30 \times 50 \mathrm{~cm} \\
\text { Each Brick: } \\
20 \times 10 \times 5 \mathrm{~cm}\end{array}$ & $\begin{array}{l}\text { Intact brick pier; hand-molded } \\
\text { bricks; two full courses; offset } \\
\text { south from original east-west } \\
\text { foundation pier alignment (rear } \\
\text { porch). }\end{array}$ & $\begin{array}{l}\text { Probable added pier } \\
\text { support for rear porch } \\
\text { when western shedroom } \\
\text { enclosed; Houston era } \\
\text { - } 1878 \text {. }\end{array}$ \\
\hline 16 & $\begin{array}{l}\text { T.P. } 55 \\
\text { C.P. N70/W70 cm }\end{array}$ & & $\begin{array}{l}\text { Collapsed brick foundation pier; } \\
\text { hand-molded bricks; two courses; } \\
\text { bottom course intact; top course } \\
\text { disturbed and fragmented. }\end{array}$ & $\begin{array}{l}\text { Probable exterior rear } \\
\text { porch support; Houston } \\
\text { era - } 1878 .\end{array}$ \\
\hline $17 * \star *$ & $\begin{array}{c}\text { T.P. } 26,29 \\
(1979)\end{array}$ & $\begin{array}{l}\text { Approximately } \\
40 \mathrm{~cm} \text { square }\end{array}$ & $\begin{array}{l}\text { Brick foundation pier; hand-molded } \\
\text { bricks; three courses; east central } \\
\text { (exterior). }\end{array}$ & $\begin{array}{l}\text { Probable exterior rear } \\
\text { porch support; Houston } \\
\text { era - } 1878 .\end{array}$ \\
\hline $18 * \star \star$ & $\begin{array}{l}\text { Trench } 1 \\
\text { T.P. } 22,26, \\
29,31(1979)\end{array}$ & $\begin{array}{l}4 \mathrm{~m} \text { long }(E / W) \\
3 \text {-course thick- } \\
\text { ness is } 65 \mathrm{~cm}\end{array}$ & $\begin{array}{l}\text { Eastern segment of hand-molded laid } \\
\text { brick coursework ( } 3 \text { courses); no } \\
\text { bonding element; portion of sil1 } \\
\text { beam directly north-center of } \\
\text { segment. }\end{array}$ & $\begin{array}{l}\text { Indeterminate function; } \\
\text { possible drainage/runoff } \\
\text { system; possible elements } \\
\text { of later outbuilding; } \\
\text { south of rear porch; } \\
\text { Houston era - 1878. }\end{array}$ \\
\hline $19 * * *$ & T.P. 39 (1979) & & $\begin{array}{l}\text { Two-brick-long segment of disturbed } \\
\text { laid brick alignment or possible } \\
\text { pier; coursework evident yet not } \\
\text { distinguishable. }\end{array}$ & $\begin{array}{l}\text { Indeterminate function; } \\
\text { possible element of } \\
\text { south entry to west } \\
\text { shed enclosure (steps); } \\
\text { Houston era - } 1878 \text {. }\end{array}$ \\
\hline $20 * \star *$ & $\begin{array}{l}\text { T.P. } 33,41 \\
43(1979)\end{array}$ & $\begin{array}{l}\text { Approximately } \\
2.75 \mathrm{~m} \text { long/ } \\
.65 \mathrm{~m} \text { wide }\end{array}$ & $\begin{array}{l}\text { Highly disturbed segment of east-west } \\
\text { laid brick alignment; scattered } \\
\text { coursework ( } 2-3 \text { courses); portion of } \\
\text { sill beam exposed within immediate } \\
\text { area (N). }\end{array}$ & $\begin{array}{l}\text { Indeterminate function; } \\
\text { possible element of } \\
\text { drainage/runoff system } \\
\text { and/or cistern outlet; } \\
\text { Houston era - } 1878 \text {. }\end{array}$ \\
\hline $21 * \star \star$ & T.P. 44 (1979) & & $\begin{array}{l}\text { Scatter brick fragment rubble; } \\
\text { approximately } 20 \text { bricks, hand- } \\
\text { molded; no coursework. }\end{array}$ & $\begin{array}{l}\text { Indeterminate function; } \\
\text { possible elements of } \\
\text { entry or laid brick } \\
\text { coursework; Houston } \\
\text { era - 1878. }\end{array}$ \\
\hline
\end{tabular}


Feature 3 (Fig. 2d) are identical to those piers noted by Clark (1980) and the feature matches the angle at which all the nineteenth century brick features are skewed (e.g., piers and chimney pad).

Feature 15 (Test Pit 54) is an intact pier measuring $25 \times 50$ centimeters and consists of two full courses of brick. Five full-sized bricks are set on the bottom course which is oriented approximately east-west. The top course is relatively undisturbed except that three of the bricks are fragmented in place. This feature was at first thought to have been a disturbed segment of a brick foundation wall (Clark 1980: 42). Further exposure, however, resulted in its identification as a secondary support pier.

Three characteristics of Feature 15 suggest that it was not part of the original porch foundation but was added slightly later; this possibly coincides with a building episode during which the southwest portion of the porch was enclosed. These characteristics are:

(1) In plan the coursework is only five bricks in length and two bricks in width; this is contrary to the apparent original piers which average six to eight bricks in length (full and one-half size) and two to four bricks in width;

(2) This difference in construction produces a rather rectangularly shaped pier rather than the almost square plan of the apparently initially constructed piers;

(3) The pier is situated slightly south of the alignment of the other four east-west foundation piers. This variation in positioning is quite evident when seen on the site plan map (Fig. 3) and coincides with the positioning of Feature 19. 


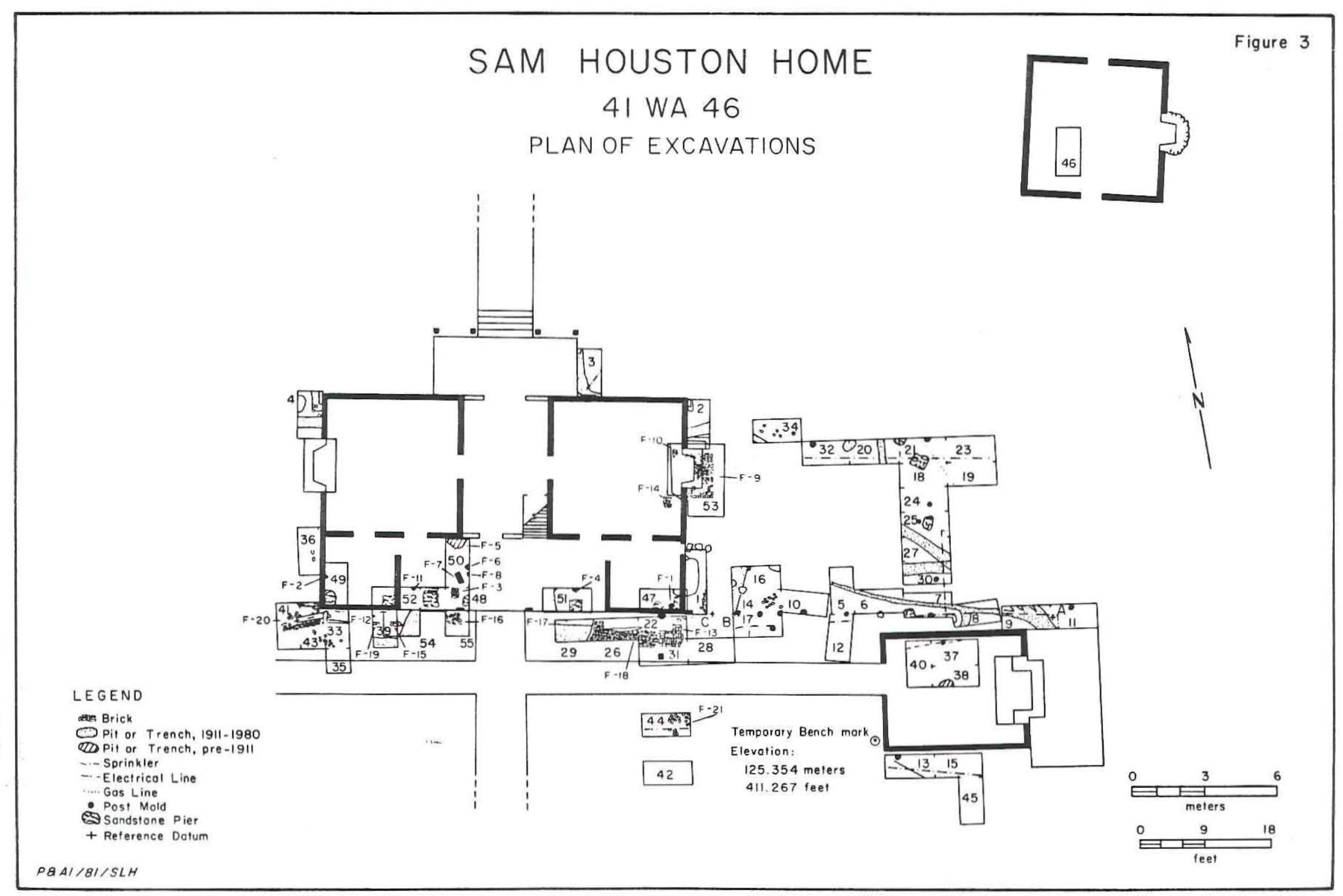


A piece of petrified wood $(10 \times 8 \times 2 \mathrm{~cm})$ was partially exposed 2-4 centimeters south of the southeast corner of Feature 15 .

Feature 16, a collapsed nineteenth century twocourse brick pier was recorded in Test Pit 55. The apparent eastward collapse of the pier resulted in the disturbance of the existing top course but left the bottom course fully intact. In plan the pier measures $35 \times 68$ centimeters; however, the original pier probably consisted of six bricks per course and was approximately 40 centimeters square. This is almost identical to the other apparent original brick pier. The use of both full and one-half size bricks is evident. A nineteenth century fragmented goblet was recorded in situ within the southeast area of pier rubble.

Feature 4, a concentration of scattered brick rubble fragments, probably represents a foundation pier that was displaced during the 1929 renovations. Approximately seven fragments were recorded but no patterning of brick placement or coursework was noted. Although there were traces of sandy lime mortar on the fragments which suggest that the feature is probably a disrupted interior support pier, the original location and amount of displacement cannot be accurately estimated.

The brick foundation piers recorded during the present and previous investigations can be divided into exterior (Features 12, 13, 15, 16, 17 and 19) (Fig. 4a) and interior (Features 3 and 4) (Fig. 4b) supports based on their location relative to the reconstruction of the rear porch (see Fig. 3). Four exterior piers, one at each corner of the porch (Features 12 and 13) and two located between these corners (one [Feature 17] 
east of and one [Feature 16] west of the center of the porch), supported the main sill beam(s). Two exterior piers (Features 15 and 19) are slightly off-center (to the west) between Feature 12 and Feature 16 piers; these two are slightly south of the main east-west alignment and may represent supplementary piers which could have supported a set of steps existing from a shedroom occupying the west end of the porch. The line of exterior piers approximately parallels the alignment of the house 3.66 meters (12 feet) from its south wall. Two interior piers, one (Feature 4) east of and one (Feature 13) west of the center of the porch, roughly parallel the exterior piers at 2.1 meters ( 7 feet) and 2.4 meters ( 8 feet) from the south wall of the house. The former (Feature 4) has been displaced slightly as noted above.

\section{Concrete Foundation Piers}

Seven concrete foundation piers were encountered during the 1980 excavations. The piers, which are aligned east to west parallel to and centered approximately 2.75 meters ( 9 feet) from the rear of the existing house location, are all apparently of twentieth century origin and are interpreted as being rear addition supports for the 1929 renovation. The piers exhibit the same construction as those reported by Clark (1980); each consists of a poured concrete block base covered by sandstone slabs laid in courses (a maximum of three courses was noted). Differences in the average depth between these piers and Clark's findings can be attributed to the grade of the existing ground surface.

The tops of the foundation piers average 50-60 centimeters square and the total thickness of the piers 
Figure 4. General Excavation Photographs

a. Test Pits 29, 26 and 22 looking east showing mid-nineteenth century exterior brick foundation piers (Features 17 and 13) and laid brick coursework (Feature 19). Structure in left of photograph is the south wall of rear porch.

b. Test Pit 48 looking north showing interior brick foundation pier (Feature 3) appearing in foreground. Post molds (Features 6 and 8), prominent square post mold (Feature 7), and miscellaneous pit (Feature 5) showing in Test Pit 50. Sandstone foundation pier in lower righthand corner dates to the 1929 renovations. 
Figure 4
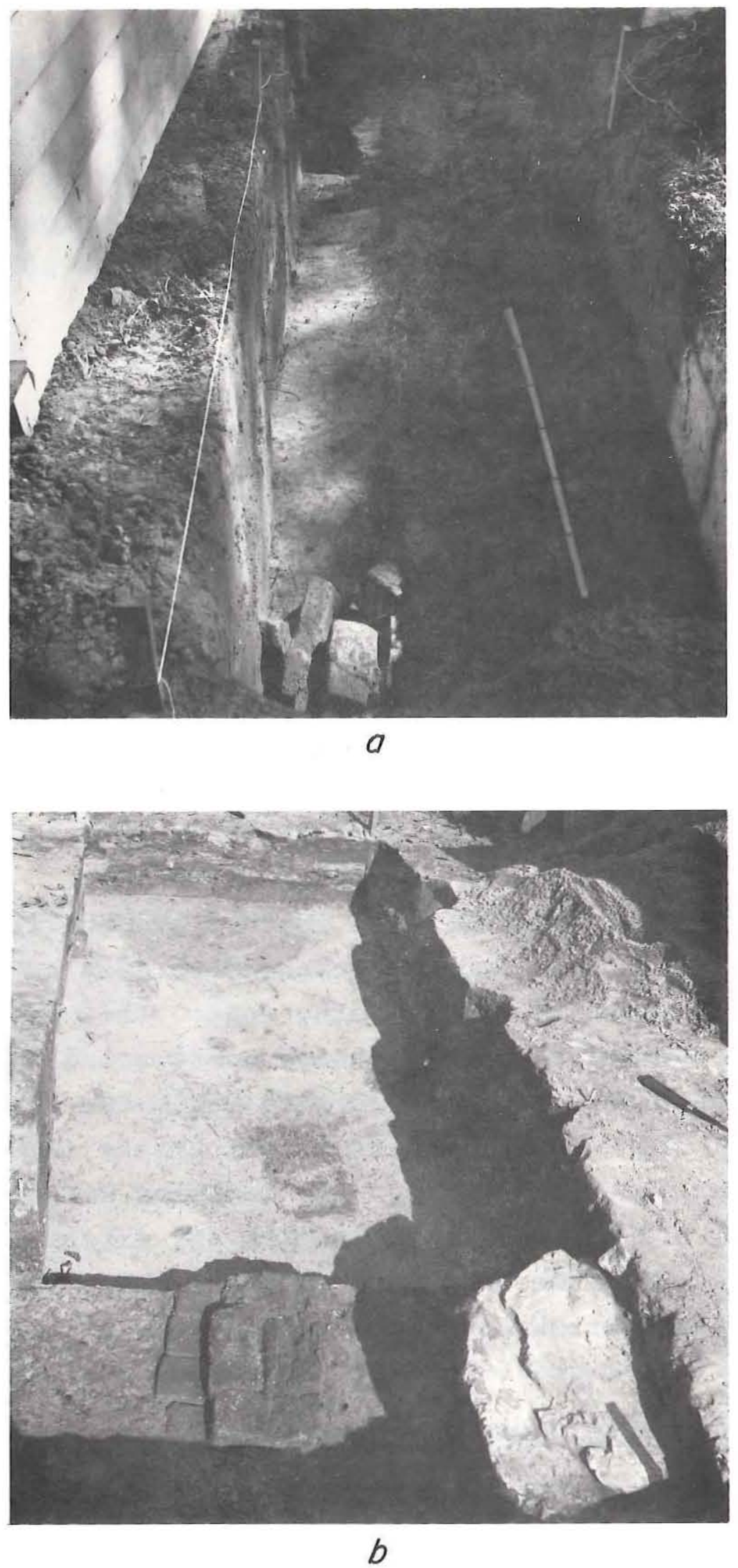
averages between 25-35 centimeters. At the southeastern and southwestern corners of the removed porch, the tops of the piers are between 5-10 centimeters below ground surface, while the intermediate piers are 10-20 centimeters below ground surface.

\section{Brick Chimney Foundation}

The most distinctive feature encountered during the 1980 excavations was a nineteenth century brick chimney pad, Feature 9 in Test Pit 53, which is contemporaneous with the other brick structural remains (Fig. 5). The pad measures $18 \times 110 \times 27$ centimeters with the top of the feature beginning approximately 45 centimeters below the ground surface. As seen in profile view, there are at least three intact courses of brick which exhibit fairly good preservation. The top course of brick has been disturbed and was covered by a thick moist sand "cushion" prior to chimney reconstruction in 1930-1936.

The bricks within the feature average $20 \times 10 \times 5$ centimeters in size and are arranged to form a U-shaped foundation with the heart facing west. This pattern, which is typical of most chimneys constructed during this period, consists of a main outside perimeter series of nine full bricks (N/S) and five full bricks (E/W) with two lesser interior series. The interior series, located at either end of the outside series and extending toward the house, form the open ends of the U-shape and consist of half-sized bricks in one alignment row alternating with the full-sized bricks in the adjacent alignment.

\section{Concrete Chimney Foundations}

The southwest corner of a concrete chimney foundation was encountered 5 centimeters below the ground 
surface in Test Pit 47. The chimney pad, which was also noted by Clark (1980) in Test Pit l, was constructed to accommodate a stone chimney placed along the east wall of the southeastern corner of the rear porch shedroom during renovations made in 1929.

According to Clark (1980: 45), the foundation "consisted of a $1.4 \mathrm{~m} \mathrm{x} .60 \mathrm{~m}$ x $.55 \mathrm{~m}$ concrete pad poured into a hand-excavated pit." That portion of the pad exposed during the 1980 excavations was similar but included at least one sandstone slab (measuring 16-19 by 8-10 centimeters) surrounded by cement bonding which was badly leached.

\section{Brick Hearth Supports}

Two brick features which appear to represent hearth supports were recorded during the present investigations. Feature 10, located in the northwestern corner of Test Pit 53, was encountered during the excavation of the east wall chimney pad (Feature 9). Feature 14 was documented later during restoration activities associated with the preparation for the new chimney foundation.

Feature 10, a concentration of brick rubble with traces of mortar, was located 40 centimeters west of the northwestern edge of the chimney pad. This roughly rectangular concentration of hand-molded brick consists of two disturbed courses with bricks averaging $20 \times 10 \times 5$ centimeters in size.

Feature 14, located approximately 40-45 centimeters west of the chimney pad's southwestern corner, was relatively undisturbed. The bricks which average $20 \times 10 \times 5$ centimeters in size were laid in two full courses to form a square averaging 30-40 centimeters in size. 
Figure 5. Original Brick Chimney Pad

a. Test Pit 53 looking south showing Feature 9, east wall chimney pad, and Feature 10, interior hearth support (lower right hand corner). Brick rubble in lower left hand corner remains from chimney removal.

b. Close-up of Feature 9, chimney pad, looking west. In profile the pad extends 27 centimeters, three full courses deep from this existing plan view. Note the fair preservation. 
Figure 5
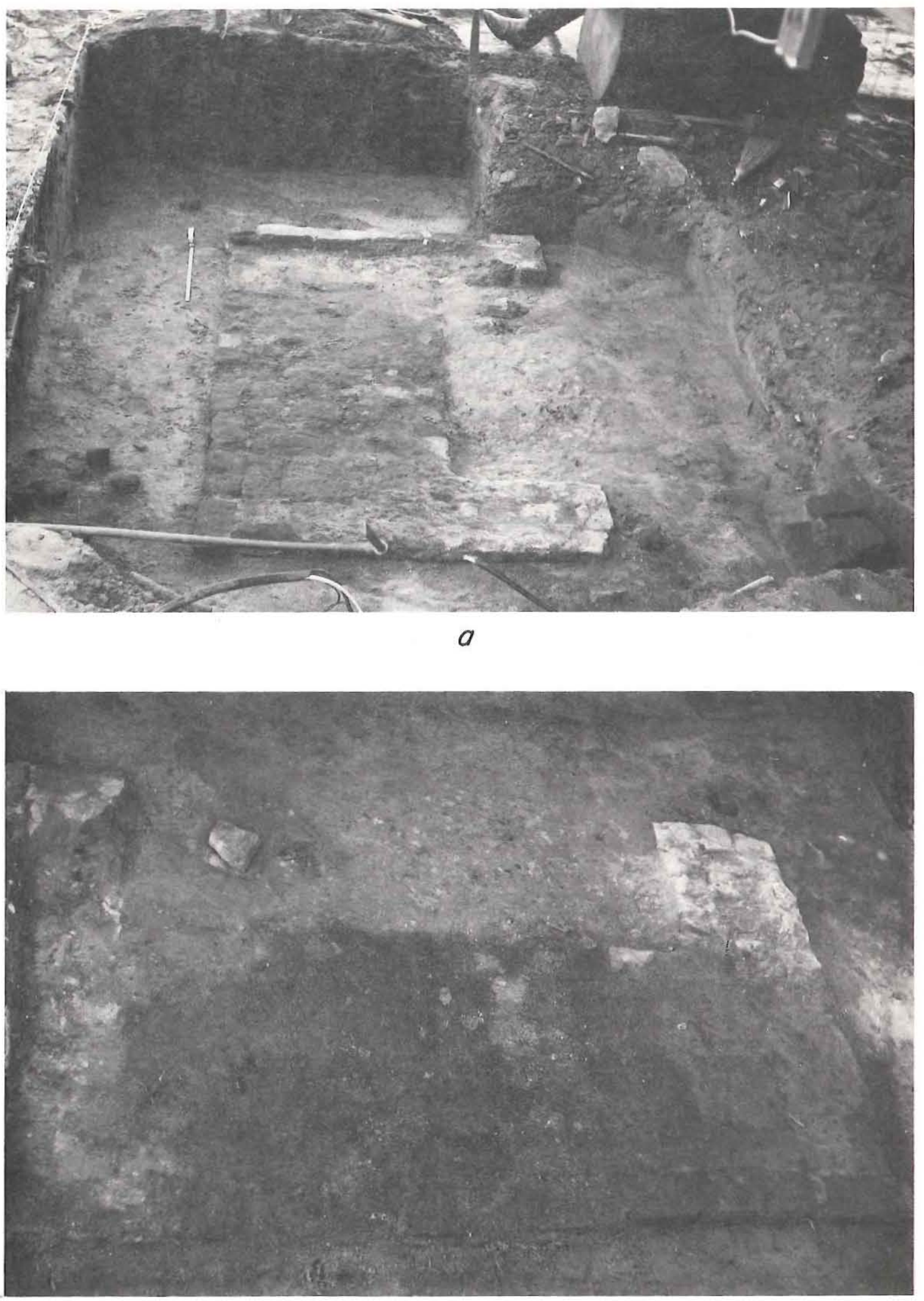
Both Feature 10 and Feature 14 were apparently constructed as balances and/or supports for the weight of the hearth which projected 40-50 centimeters westward (into the house) from the original firebox.

Post Molds

A total of six post molds, two rectangular in plan (Features 7 and 8) and four cylindrical in plan (Features 1, 2, 6 and 11) were recorded in Test Pits $48,49,50$ and 52; all were located directly beneath the rear additions (Fig. $4 b$ ). No evidence of specific alignments or arrangements of the features were noted which might provide indications of their purpose. The only potentially diagnostic materials recovered from the feature matrix were wood fragments from Feature 2 and a fragment of barbed wire dating to around the turn of the century from Feature 1 .

Little information concerning the post molds is certain although some of them probably post-date the removal of Houston's home from its original location in 1905. The two rectangular posts recorded may or may not be associated with those found by Clark in Test Pits 1, 16 and 31. A lack of direct artifact associations ! precludes specific dating of the rectangular post molds although it may be postulated that this type of post is most likely associated with the nineteenth century occupations of the house. The circular post molds probably are related either to the Smedes occupation (1878-1905) or the later events at the site.

$\underline{\text { Pits }}$

A pit encountered in Test Pit 50 was recorded as Feature 5 and was partially excavated (Fig. $4 b$ ). 
The oval basin-shaped pit which measures $80 \times 55$ centimeters with a maximum depth of 14 centimeters contained wood fragments, flecks of charcoal and several small nineteenth century brick fragments. Feature matrix was a grey-brown sandy loam mottled with basal clay. The brick fragment inclusions and the positioning of the shallow pit strongly suggest that an original foundation pier was removed from this location following the removal of the house in 1905. This interpretation, however, cannot be substantiated on the basis of the present evidence.

Nonarcheological Features

A brief discussion of nonarcheological features is included in keeping with Clark's emphasis on natural and cultural disturbances and their effects on the site over the course of 133 years of varied use.

Worm Tubes

Numerous earthworm tubes and insect holes were noted (see Clark 1980: 45).

\section{$\underline{\text { Rodent Runs }}$}

None noted.

$\underline{\text { Root Casts }}$

One root cast and numerous live roots were encountered in Test Pit 46 inside the Law Office. A smaller root cast was also observed within Feature 1 in Test Pit 47.

\section{Plow Zone}

Actual plow scars were not observed in any test unit excavated during 1980. This is attributable to the fact that the units were placed under the removed rear additions 
to the house and inside the Law Office. Both of these structures were at their present locations at the time of the Sam Houston State University Agriculture Department activities (Clark 1980: 17).

The presence of a highly disturbed zone of light medium brown sandy loam averaging 25 centimeters in thickness in the Law Office (Test Pit 46) and 30-35 centimeters thick in the south rear porch addition area, however, should be noted. Clark mentions that artifacts in this zone date from the early-to-mid-twentieth century, as shown by the 1979 and 1980-81 excavations. The origin of this zone has not been precisely documented and is not necessarily considered as a plow zone for the 1980-81 investigations (see Soils section of Ehis report).

Sprinkler Lines

The sprinkler system noted by Clark in Test Pit 2 was also encountered in Test Pit 53.

\section{Electrical Lines}

An electrical line "laid in a galvanized iron $2.54 \mathrm{~cm}$ diameter pipe" (Clark 1980: 47) was encountered by Clark in Test Pit 33 and was encountered again in the south end of Test Pit 49 during the 1980 testing program. The line runs the east-west width of Test Pit 49 and parallels the south wall at approximately 20 centimeters below the ground surface.

Another electrical line noted in Clark's Test Pits 4, 5, 7, 8, 9 and 16 was noted in Test Pit 53 some distance northwest of those units. The wires had been removed during restoration preparations prior to the 1980 excavations. 


\section{Air Conditioner Pipes}

All of these items were removed prior to the 1980-81 excavation to facilitate restoration activities.

\section{The Artifacts}

A total of 5,595 artifacts was recovered during the 1980-81 investigations at the Houston Home and Law Office. These-were recovered both during testing and monitoring activities carried out at the site. The artifacts correspond closely with the categories previously described by Clark (1980: 65-154). Rather than repeat the descriptions provided by $\mathrm{Clark}$, the artifacts recovered during the current investigations are presented in tabular form only in Tables 2, 3, 4 and 5. For descriptive treatment of similar artifacts, the reader is referred to those made by clark cited above.

\section{SUMMARY AND CONCLUSIONS}

The archeological investigations conducted during 1980 and 1981 have made a qualitative difference in the understanding of past and present activities and conditions at the Sam Houston Home, "The Woodlands." It is now possible (1) to make conclusive statements concerning certain questions raised prior to Clark's investigations in 1979; (2) to attempt a reconstruction of the Home during the period between 1847 and 1878; and (3) to assess the impact of the current and planned activities associated with the restoration of the site.

\section{Previous Archeological Questions}

Information derived from the location of the subsurface architectural remains uncovered, especially the 
TABLE 2

TESTING ARTIFACT PROVENIENCE

\begin{tabular}{|c|c|c|c|c|c|c|c|c|c|c|c|c|c|c|c|c|c|c|c|c|c|c|}
\hline \multirow[b]{2}{*}{ Description } & \multicolumn{2}{|c|}{ TP46 } & \multicolumn{2}{|c|}{ TP47 } & \multirow[b]{2}{*}{ L3 } & \multicolumn{2}{|c|}{ TP48 } & \multicolumn{2}{|c|}{ TP49 } & \multirow[b]{2}{*}{$2 \mathrm{Fill}$} & \multicolumn{2}{|c|}{ TP50 } & \multicolumn{3}{|c|}{ TP51 } & \multicolumn{3}{|c|}{ TP52 } & \multicolumn{2}{|c|}{ TP53 } & \multirow[b]{2}{*}{ Troweling } & \multirow[b]{2}{*}{ TOTAL } \\
\hline & LI & L2 & LI & L2 & & LI & L2 & LI & L2 & & LI & L2 & LI & L2 & L3 & LI & L2 & L3 & LI & L2 & & \\
\hline \multicolumn{23}{|l|}{ CERAMICS: } \\
\hline \multicolumn{23}{|l|}{ Earthenware: } \\
\hline Plain Body & 5 & 2 & 7 & 2 & 1 & 6 & 8 & 6 & 3 & - & 8 & - & 1 & 8 & 21 & 1 & 3 & 4 & 6 & 3 & - & 95 \\
\hline Plain Rim & 1 & 1 & 1 & 2 & - & 1 & 1 & 1 & 1 & - & 5 & 3 & - & 1 & 3 & - & 3 & 3 & 1 & 1 & - & 29 \\
\hline Plain Base & 3 & - & - & - & - & 1 & - & - & - & - & - & - & - & 1 & - & - & 2 & - & 3 & - & - & 10 \\
\hline Plain Handle & - & - & - & - & 3 & 1 & - & - & - & - & - & - & - & - & 1 & - & - & - & - & - & - & 5 \\
\hline Gilt-banded & - & - & - & - & - & - & - & - & - & - & - & - & - & - & - & - & - & - & 1 & 2 & - & 3 \\
\hline Maker's Mark & - & - & - & - & - & 1 & - & - & - & - & - & - & - & 2 & - & 1 & - & - & 1 & 1 & - & 6 \\
\hline Embossed Body & - & - & - & - & - & - & - & 1 & - & - & - & 1 & - & - & - & - & - & - & - & - & - & 2 \\
\hline Embossed Rim & - & - & - & - & - & - & - & - & - & - & - & - & - & 1 & 1 & - & - & - & - & - & - & 2 \\
\hline Embossed Finial & - & - & - & - & - & - & - & - & - & - & - & 1 & - & - & - & - & - & - & - & - & - & 1 \\
\hline \multicolumn{23}{|l|}{ Transfer-Printed Ware: } \\
\hline Base & - & - & - & - & - & - & - & 2 & - & - & - & - & - & - & - & - & - & - & - & - & - & 2 \\
\hline Transfer Blue Body & - & - & - & 1 & - & - & - & - & 2 & - & - & 1 & - & - & - & - & - & - & - & - & - & 4 \\
\hline Transfer Blue Rim & 1 & - & - & - & - & - & - & 1 & - & - & - & - & - & - & - & - & - & - & - & - & - & 2 \\
\hline Transfer Red Body & 1 & 1 & - & - & - & - & - & - & - & - & - & - & - & - & - & - & - & - & - & - & - & 2 \\
\hline Transfer Brown Rim & - & - & - & - & - & - & - & - & - & - & - & - & - & - & - & - & - & 1 & - & - & - & 1 \\
\hline Transfer Brown Hand-Painted & - & - & - & - & - & - & - & - & - & - & - & - & - & - & - & 1 & - & - & - & - & - & 1 \\
\hline \multicolumn{23}{|l|}{ Creamware: } \\
\hline Plain Body & - & - & - & - & - & 1 & - & - & - & - & - & - & - & 3 & - & - & - & - & 1 & - & - & 5 \\
\hline Blueware Body & 1 & - & - & - & - & - & - & - & - & - & - & - & - & - & - & - & - & - & - & - & - & 1 \\
\hline Brownware Body & - & - & - & - & - & - & 1 & - & - & - & 1 & - & 2 & - & 2 & - & - & - & - & - & - & 6 \\
\hline \multicolumn{23}{|l|}{ Stoneware: } \\
\hline Plain Body & - & - & - & - & - & - & - & - & - & - & - & - & - & - & - & - & - & - & 2 & 2 & - & 4 \\
\hline Grey Body & - & - & - & - & - & 1 & 1 & - & - & - & - & - & - & - & - & - & 1 & - & - & - & - & 3 \\
\hline Brown Body & 2 & - & 2 & - & - & - & - & - & - & - & - & - & - & - & - & - & - & - & - & - & - & 4 \\
\hline Blue Transfer Rim & - & - & - & - & - & - & - & - & - & - & - & - & - & - & - & - & - & - & - & 1 & - & 1 \\
\hline Pink Body & - & - & $a$ & - & - & - & - & - & - & - & - & - & - & - & - & - & - & - & - & - & 1 & 1 \\
\hline
\end{tabular}


TABLE 2, Continued

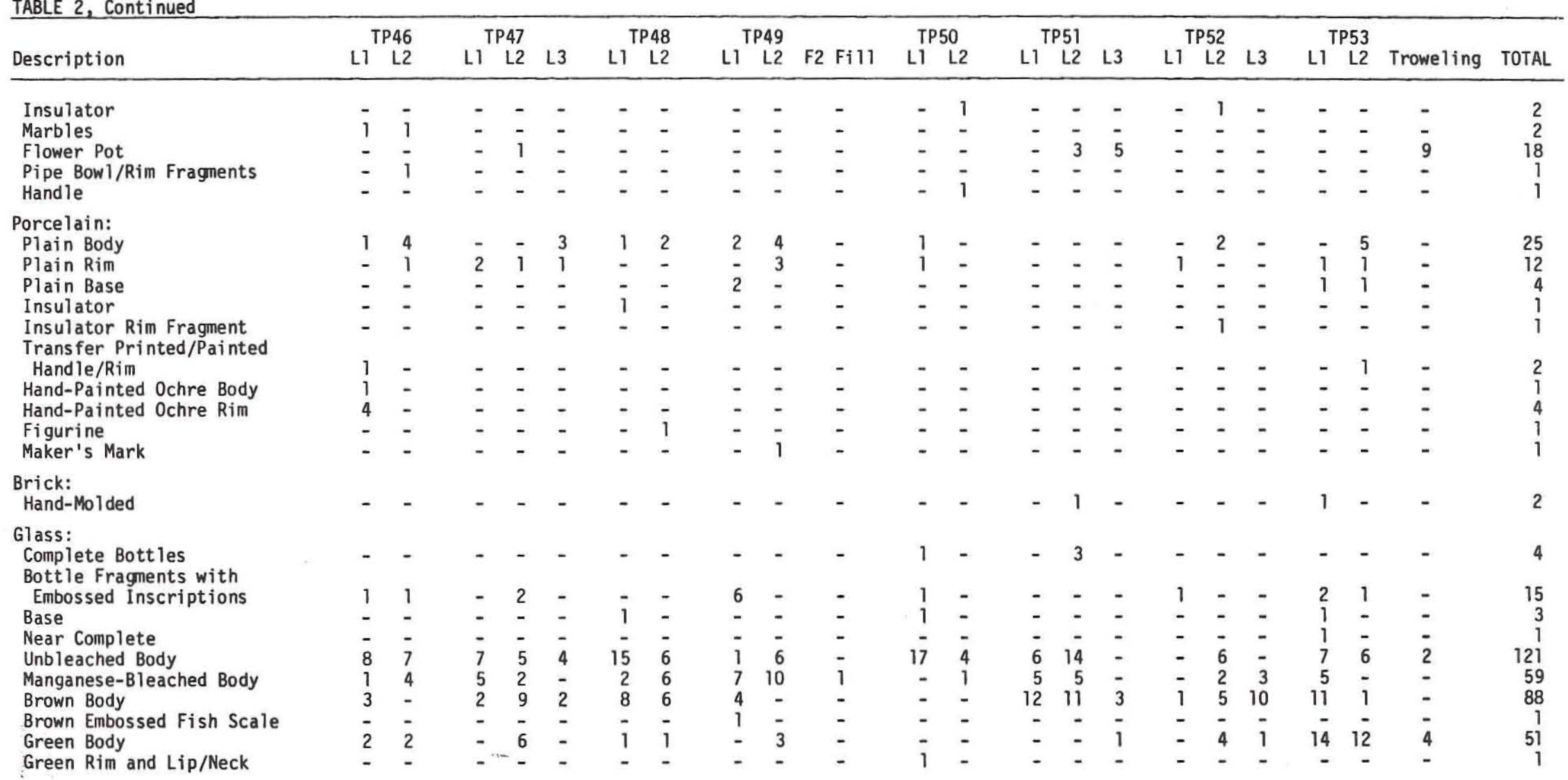


TABLE 2, Continued

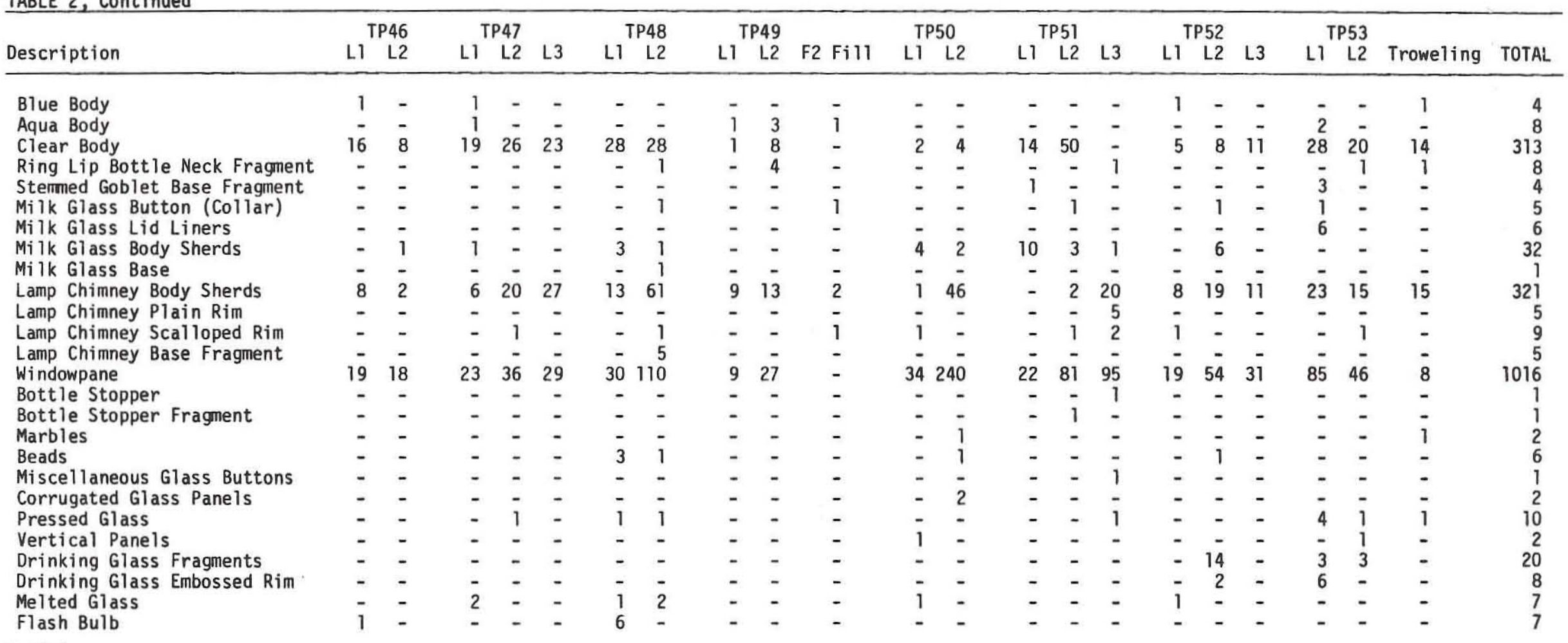

METALS:

Iron:

Cut Nails

Cut Nail Fragments

Wire Nails

Wire Nail Fragments

Unidentified Nails

and Fragments

$\begin{array}{rrrrrrrrr}9 & 14 & 2 & 9 & 15 & 6 & 5 & 4 & 6 \\ 56 & - & - & - & - & - & - & - & - \\ - & - & 50 & 27 & 23 & 104 & 75 & 37 & 28 \\ 26 & 21 & - & - & - & - & - & - & - \\ & & 5 & 5 & 74 & 50 & 90 & 27 & 29\end{array}$

$\begin{array}{rr}9 & 75 \\ - & 1 \\ 165 & 80 \\ -\quad- \\ \end{array}$

$\begin{array}{rrr}7 & 6 & 8 \\ - & 1 & - \\ 91 & 54 & 205 \\ - & - & -\end{array}$

$\begin{array}{rrr}3 & - & - \\ - & - & - \\ 51 & 14 & - \\ - & - & 29\end{array}$

$\begin{array}{rr}17 & 7 \\ - & - \\ 35 & 8\end{array}$

206

$37 \quad 86 \quad 160$

- 8628

$13 \quad 18$

1062
73

864 
TABLE 2, Continued

\begin{tabular}{|c|c|c|c|c|c|c|c|c|c|c|c|c|c|c|c|c|c|c|c|c|c|c|}
\hline Description & \multicolumn{2}{|c|}{ TP46 } & \multicolumn{2}{|c|}{ TP47 } & L3 & \multicolumn{2}{|c|}{ TP48 } & \multicolumn{2}{|c|}{ TP49 } & F2 Fill & \multicolumn{2}{|c|}{ TP50 } & \multicolumn{2}{|c|}{ TP51 } & L3 & \multicolumn{2}{|c|}{ TP52 } & L3 & \multicolumn{2}{|c|}{ TP53 } & Troweling & TOTAL \\
\hline Fence Staples & 1 & - & - & - & - & 3 & 1 & 1 & - & - & - & - & - & - & - & - & 1 & - & - & - & - & 7 \\
\hline Hinge & - & - & - & - & - & - & - & - & - & - & - & - & - & 1 & - & - & - & - & - & - & - & $i$ \\
\hline Barbed Wire & - & - & - & - & 1 & - & - & - & 3 & - & - & - & - & - & - & - & - & - & - & - & - & 4 \\
\hline Cast Iron & - & 1 & - & - & - & - & - & - & - & - & - & 9 & - & - & - & 9 & - & - & - & - & - & 19 \\
\hline Sheet Iron & 7 & 6 & - & 8 & 8 & 11 & 7 & - & 2 & 2 & 37 & 3 & 8 & 17 & - & - & 3 & - & 6 & 1 & - & 126 \\
\hline Chunk Iron & - & - & - & - & - & - & - & 1 & - & - & - & - & - & - & - & - & - & - & - & - & - & 1 \\
\hline Pin & - & - & - & - & 1 & - & - & - & - & - & - & - & - & - & - & - & 1 & - & - & - & - & 2 \\
\hline Wire & - & 1 & - & - & - & - & - & - & - & - & 1 & - & - & 1 & - & - & - & - & 1 & 1 & - & 5 \\
\hline Unidentified Objects & & 12 & - & - & 1 & - & 2 & - & - & - & 38 & 1 & - & 42 & - & - & 50 & 16 & 13 & - & - & 175 \\
\hline Safety Pin & - & - & - & - & - & - & - & - & - & - & - & - & - & - & 1 & - & - & - & - & - & - & 1 \\
\hline Screw, Round Head & - & & - & - & - & 1 & - & - & - & - & - & - & - & - & - & - & - & - & - & - & - & 1 \\
\hline Screw, Flat Head & & - & - & - & - & 1 & - & - & - & - & - & - & - & - & - & - & - & - & - & - & - & 1 \\
\hline Paper Clip & - & & - & - & - & - & - & - & - & - & - & - & 1 & - & - & - & - & - & - & - & - & 1 \\
\hline Thumb Tacks & - & - & - & - & - & 2 & - & - & - & - & - & 6 & - & - & - & - & - & - & - & - & - & 8 \\
\hline Door Latch & - & - & - & - & - & - & - & - & - & - & - & - & - & - & - & - & 1 & - & - & - & - & 1 \\
\hline Handle Fragments & - & - & - & - & - & - & - & - & - & - & - & 2 & - & - & - & - & - & - & - & - & - & 2 \\
\hline Bottle Cap & - & - & - & - & - & - & - & - & - & - & $\bar{z}$ & - & - & - & - & - & - & - & 1 & - & - & 1 \\
\hline Toy Object & - & - & - & - & - & - & - & - & - & - & 1 & - & - & - & - & - & - & - & - & - & - & 1 \\
\hline Spur & - & - & - & - & - & - & - & - & - & - & - & 1 & - & - & - & - & - & - & - & - & - & 1 \\
\hline \multicolumn{23}{|l|}{ Aluminum: } \\
\hline $\begin{array}{l}\text { Bottle Cap } \\
\text { Tin Can }\end{array}$ & $\overline{-}$ & $\overline{-}$ & $\bar{i}$ & $\begin{array}{l}- \\
-\end{array}$ & - & $\overline{5}$ & - & - & - & - & - & 1 & 2 & - & - & 1 & - & - & - & - & - & 4 \\
\hline Corrugated Tubing Fragment & - & $\overline{-}$ & - & $\begin{array}{l}- \\
-\end{array}$ & - & 2 & - & - & - & - & - & $\bar{j}$ & $\overline{-}$ & - & - & - & $\overline{-}$ & $\overline{-}$ & - & - & $\overline{-}$ & 3 \\
\hline $\begin{array}{l}\text { Corrugated lubing rragment } \\
\text { Flashbulb Base }\end{array}$ & 1 & - & - & - & - & $\overline{-}$ & $\overline{2}$ & $\overline{-}$ & $\overline{-}$ & $\overline{-}$ & $\overline{1}$ & - & $\overline{3}$ & $\overline{2}$ & - & $\overline{-}$ & $\overline{-}$ & $\overline{-}$ & $\overline{-}$ & $\overline{-}$ & $\overline{-}$ & 9 \\
\hline Disc & - & - & - & - & - & - & - & - & - & - & 1 & - & - & - & - & - & - & - & - & - & - & 1 \\
\hline Foil & - & - & - & - & - & - & - & - & - & - & 1 & - & 7 & 1 & - & - & - & - & - & - & - & 9 \\
\hline Zinc Sheet Flashing Fragments & 2 & - & - & - & - & - & - & - & - & - & - & - & - & - & - & - & - & - & - & - & - & 2 \\
\hline \multicolumn{23}{|l|}{ Copper: } \\
\hline Collar & - & - & - & - & - & - & - & - & - & - & - & 1 & - & - & - & - & - & - & - & - & - & 1 \\
\hline Nut & - & - & - & - & - & 1 & - & - & - & - & - & - & - & - & - & - & - & - & - & - & - & 1 \\
\hline Twist Cap Fragments & - & - & - & - & - & 8 & - & - & - & - & - & - & - & - & - & - & - & - & - & - & - & 8 \\
\hline Grommet & - & - & - & - & - & - & - & 1 & - & - & - & - & - & - & - & - & - & - & - & - & - & 1 \\
\hline Penny, 1902 Indian Head & - & - & - & - & - & - & - & - & - & - & - & 1 & - & - & - & - & - & - & - & - & - & 1 \\
\hline Seal 1 & - & - & - & - & - & - & - & - & - & - & - & - & - & 1 & - & - & - & - & - & - & - & 1 \\
\hline
\end{tabular}


TABLE 2, Continued

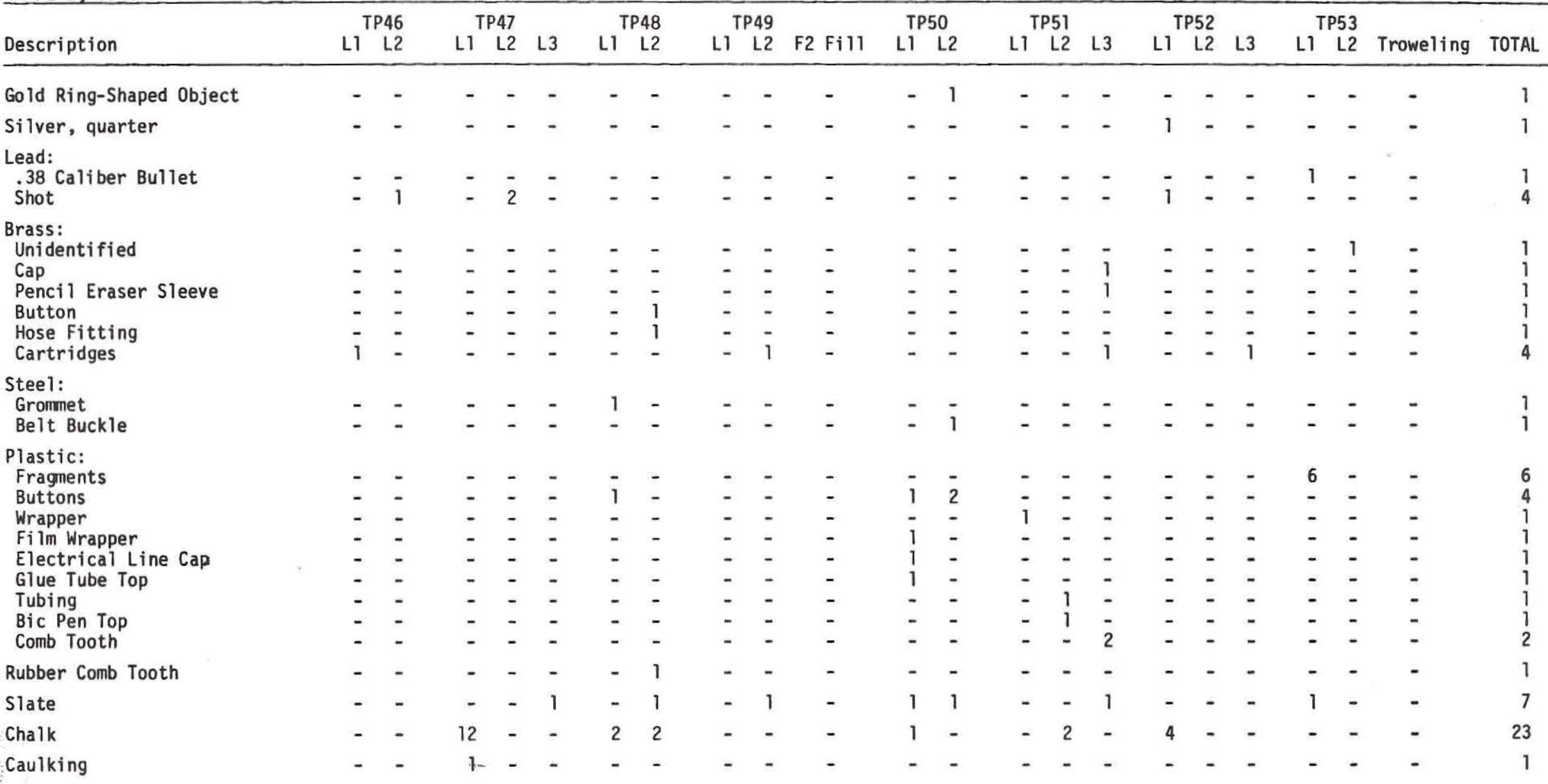


TABLE 2, Continued

$\begin{array}{lllllllllll} & \text { TP46 } & \text { TP47 } & \text { TP48 } & \text { TP49 } & \text { TP50 } & \text { TP51 } & \text { TP52 } & \text { TP53 }\end{array}$

Description

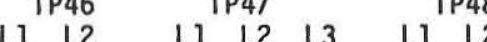

LI L2 F2 Fill L1 L

L1 $\quad$ L 12

L1 L2 L3 LI L2 Troweling TOTAL

Brick Fragments

Brick Fragments, Burned

Brick Fragments, Glazed

Mortar

Lime

Sandstone

Concrete

Red Paint on Wood

Mute Blue Paint on Wood

White Paint on Wood

Grey Paint on Wood

Stones

Chert, Abraded

$\omega$ Bone Artifacts:

Button

Worked Bone Fragment

Pipe Stem

Animal Bone Fragments

Calcined Bone Fragments

Mammalian Vertebrae

Tooth

Small Animal Mandible Fragment

Cow Bone

Eggshel1

Leather Strap

Shell Artifacts:

Button

\begin{tabular}{|c|c|c|c|c|c|c|c|c|c|c|c|c|c|c|c|c|c|c|c|c|}
\hline 2 & 7 & - & - & 2 & 3 & 2 & - & & - & 1 & - & - & 1 & - & - & - & . & 1 & . & 9 \\
\hline - & - & - & - & - & - & - & - & - & - & - & - & - & - & - & - & - & . & - & . & 2 \\
\hline - & - & - & - & - & - & - & - & - & - & - & - & - & - & - & - & - & . & 1 & & - \\
\hline 1 & 3 & 1 & - & - & 10 & - & - & 5 & - & - & - & - & - & - & - & - & . & 1 & & - \\
\hline - & - & - & - & - & - & - & - & - & - & - & - & - & - & - & - & - & & - & & 2 \\
\hline 1 & 1 & - & - & - & 2 & - & - & - & - & - & 1 & - & 1 & - & - & - & . & - & & - \\
\hline 1 & - & - & - & - & - & - & - & - & - & 2 & - & - & 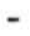 & - & - & - & 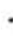 & - & & - \\
\hline - & - & - & - & - & - & - & - & - & - & - & - & - & - & - & 1 & - & & - & & - \\
\hline - & - & 10 & - & - & - & - & - & - & - & - & - & 3 & - & - & - & - & . & - & & - \\
\hline- & - & - & - & - & - & - & - & - & - & - & - & 1 & - & - & - & - & 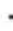 & - & & - \\
\hline - & - & - & - & - & 4 & - & - & - & - & - & - & - & - & - & - & - & & - & & - \\
\hline - & - & - & - & - & - & - & - & - & - & - & 1 & - & - & - & - & - & . & - & & - \\
\hline- & - & - & - & - & - & - & - & - & - & - & 1 & - & - & - & - & - & & - & & - \\
\hline
\end{tabular}

Hand le 
TABLE 2, Continued

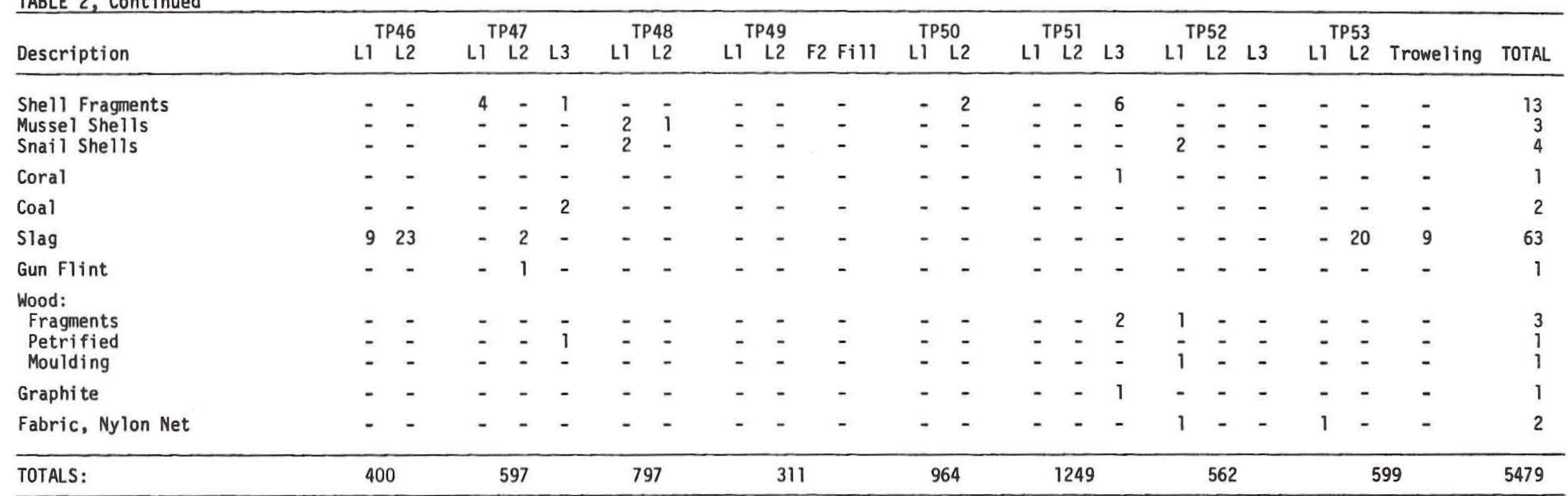




\section{TABLE 3}

TRENCH 1 ARTIFACT PROVENIENCE

$\begin{array}{lr}\text { Ceramic: } & \\ \text { Porcelain: } & 1 \\ \text { Embossed rim fragment } & 1 \\ \text { Brick: } & \\ \text { Hand-molded glazed } & 5 \\ \text { Glass: } & \underline{1} \\ \text { Manganese-bleached body } & 8 \\ \text { Aqua body } & 8 \\ \text { TOTAL: } & \end{array}$

TABLE 4

MONITORING, TEST PIT 55

\section{Ceramic:}

Whiteware base sherd (saucer)

with black ink maker's mark

Glass:

Green bottle glass body fragment

Manganese bottle glass rim fragment

Manganese bottle glass body fragment

Fragmented clear glass goblet (hock wine)

5

1

8

3 base fragments (near complete)

2 body fragments

2 rim fragments

1 complete stem

Drinking glass, pressed, rim fragment

Lamp chimney fragment

19th Century (thin) windowpane fragments 3

\section{Metal:}

Cut nail fragments

Wire nail fragments

Unidentified nail fragments

1

1

1

Bone:

Hand-cut (sawed) steak bone fragment

Small rodent burned bone fragment 
TABLE 5

MONITORING PROVENIENCE CHART

\begin{tabular}{|c|c|c|c|c|c|c|c|}
\hline Description & TP53 & SW & SE & NER & $\mathrm{NE}$ & $\begin{array}{c}\text { NE Corner } \\
\text { Pier }\end{array}$ & $\begin{array}{l}\text { E PROPER } \\
\text { E-W Trench Extending } \\
\text { from SE to SW Corners }\end{array}$ \\
\hline $\begin{array}{l}\text { Earthenware: } \\
\text { Plain body } \\
\text { Plain rim } \\
\text { Hand-painted (green) } \\
\text { Green ware }\end{array}$ & $\begin{array}{l}- \\
\overline{1} \\
1\end{array}$ & $\begin{array}{l}1 \\
1 \\
- \\
-\end{array}$ & $\begin{array}{l}1 \\
- \\
- \\
-\end{array}$ & $\begin{array}{l}- \\
- \\
-\end{array}$ & $\begin{array}{l}- \\
- \\
-\end{array}$ & $\begin{array}{l}- \\
- \\
1\end{array}$ & $\begin{array}{l}- \\
- \\
-\end{array}$ \\
\hline $\begin{array}{l}\text { Porcelain: } \\
\text { Plain rim } \\
\text { Commode base }\end{array}$ & - & - & - & $\begin{array}{l}- \\
-\end{array}$ & - & $\overline{3}$ & $\begin{array}{l}1 \\
-\end{array}$ \\
\hline $\begin{array}{l}\text { Glass: } \\
\text { Complete bottles } \\
\text { Embossed inscription } \\
\text { body sherds } \\
\text { Unbleached } \\
\text { Green } \\
\text { Clear } \\
\text { Pressed glass scalloped } \\
\text { rim } \\
\text { Chandelier prism } \\
\text { Windowpane } \\
\text { Lamp chimney } \\
\text { Milk glass } \\
\text { Blue glass button }\end{array}$ & $\begin{array}{r}- \\
1 \\
3 \\
5 \\
- \\
1 \\
1 \\
22 \\
8 \\
- \\
-\end{array}$ & $\begin{array}{l}- \\
\overline{5} \\
- \\
- \\
-\end{array}$ & $\begin{array}{l}- \\
- \\
- \\
- \\
-\end{array}$ & $\begin{array}{l}- \\
- \\
- \\
- \\
- \\
- \\
- \\
- \\
- \\
- \\
-\end{array}$ & $\begin{array}{l}- \\
- \\
- \\
-\end{array}$ & $\begin{array}{l}- \\
- \\
- \\
- \\
- \\
- \\
- \\
- \\
- \\
1 \\
-\end{array}$ & $\begin{array}{l}1 \\
- \\
- \\
1 \\
- \\
- \\
- \\
- \\
- \\
- \\
-\end{array}$ \\
\hline $\begin{array}{l}\text { Iron: } \\
\text { Cut nails } \\
\text { Wire nails } \\
\text { Unidentified nail frag. } \\
\text { Bottle cap }\end{array}$ & $\begin{array}{l}5 \\
2 \\
- \\
-\end{array}$ & $\begin{array}{l}1 \\
- \\
- \\
-\end{array}$ & $\begin{array}{l}- \\
- \\
1\end{array}$ & $\begin{array}{l}1 \\
2 \\
- \\
-\end{array}$ & $\begin{array}{l}- \\
1 \\
-\end{array}$ & $\begin{array}{l}- \\
- \\
-\end{array}$ & $\begin{array}{l}- \\
- \\
-\end{array}$ \\
\hline
\end{tabular}


Table 5, Continued.

\begin{tabular}{l|c|ccc|cc}
\hline & & \multicolumn{3}{|c|}{ LAW OFFICE CORNER PIERS } & \multicolumn{2}{c}{ HOUSE PROPER } \\
Description & TP53 & SW & SE & NW & NE & $\begin{array}{c}\text { NE Corner } \\
\text { Pier }\end{array}$ \\
\hline from SE to SW Corners
\end{tabular}


original east wall chimney pad, demonstrates that the placement of the house in 1911 corresponds well with the original location of the house. The Home, as relocated, is 20 centimeters (less than 1 foot) east and north of the original location and has a slightly more westward orientation (Fig. 6 ).

Although the type of the original chimney has not been determined, the present investigations have shown that the home as originally constructed did have a chimney in the approximate location of the chimney built during 1936. The nature of the pad which supported the original chimney has also been determined. This pad, which was previously thought to have been destroyed but was covered by the 1936 chimney, is relatively intact and consists of mid-nineteenth century hand-molded low temperature fired bricks arranged in a U-shape with the open end facing the interior of the house to the west.

\section{Reconstruction of "The Woodlands" Home}

The following reconstruction of "The Woodlands" Home is based on the nature of the existing structure, previous research and investigations, and interpretations of the architectural features defined during the present investigations.

House: The structure is a one and one-half story central hall house constructed by placing two pens gableto-gable separated by an enclosed hallway and covered by a single roof (Jordan 1978: 133). The chimney, which was centered in a gabled wall (east) and extended up to and above the peak of the gable, was freestanding brick masonry surrounded by the wide eave roof. The 


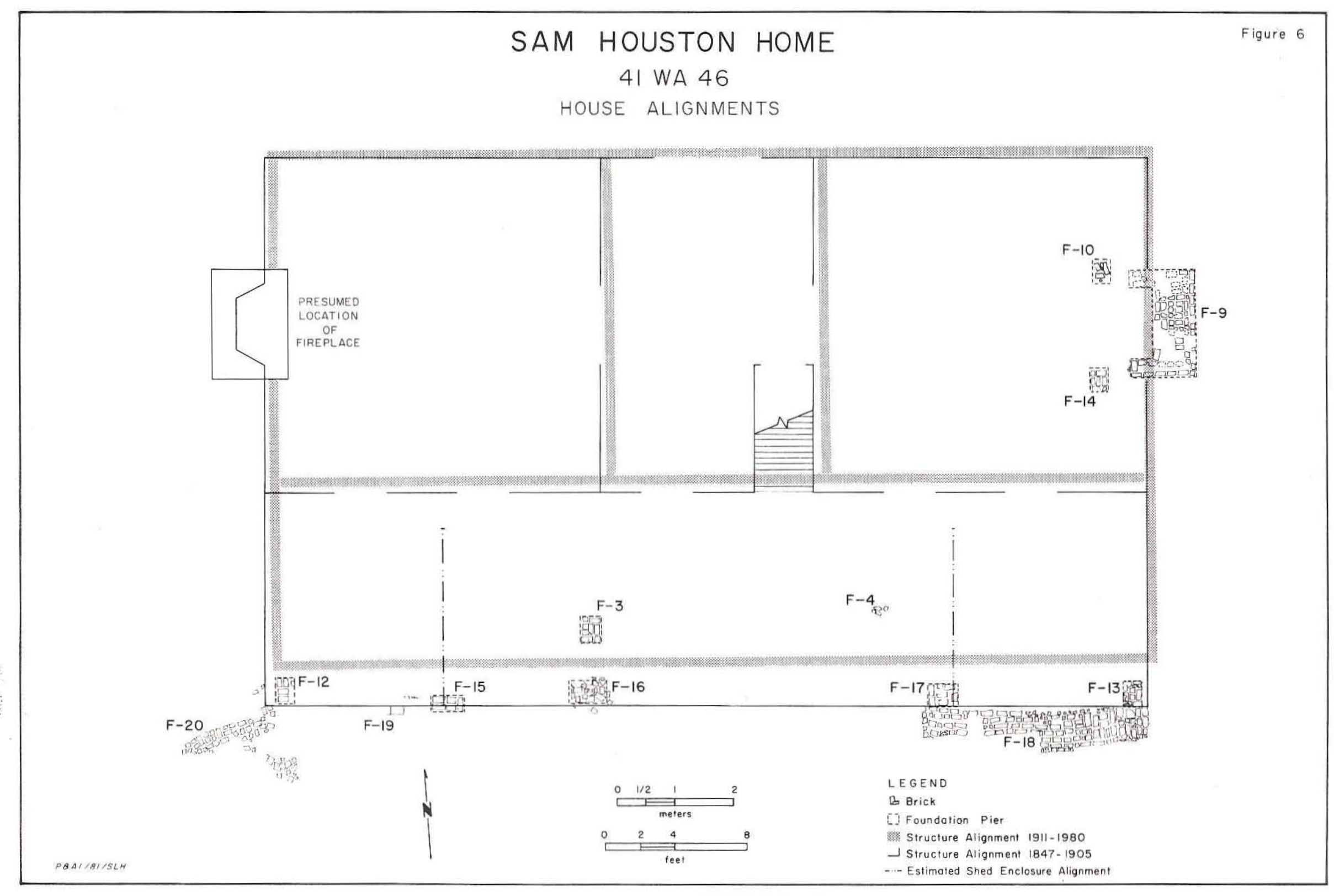


firebox was further extended by an interior hearth which projected west (from the firebox) and rested on the floor (joists), which in turn rested on northwest and southwest masonry corner support footings (Table 6).

TABLE 6

METRIC DATA FOR HOUSE

\begin{tabular}{|c|c|}
\hline $\mathrm{N}-\mathrm{S}$ width of House & $5.75 \mathrm{~m}\left(19^{\prime}\right)$ \\
\hline E-W length of House & $15.2 \mathrm{~m}\left(49^{\prime} 4^{\prime \prime}\right)$ \\
\hline NE corner of House to center of fireplace & $2.75 \mathrm{~m}\left(9^{\prime}\right)$ \\
\hline SE corner of House to center of fireplace & $3.0 \mathrm{~m}\left(10^{\prime}\right)$ \\
\hline $\begin{array}{l}\text { Firebox - interior } \\
\text { Firebox - exterior }\end{array}$ & $\begin{array}{l}.475 \mathrm{~m}\left(1^{\prime} 5^{\prime \prime}\right) \\
.732 \mathrm{~m}\left(2^{\prime} 4^{\prime \prime}\right)\end{array}$ \\
\hline $\begin{array}{l}\text { SW and NW corners of firebox to } \\
\text { hearth supports }\end{array}$ & $.40 \mathrm{~m}\left(1^{\prime} 3^{\prime \prime}\right)$ \\
\hline \multicolumn{2}{|l|}{ Feature 9 - chimney pad } \\
\hline \multicolumn{2}{|l|}{ Feature $10-\mathrm{NW}$ hearth support } \\
\hline Feature 14 - SW hearth support & \\
\hline
\end{tabular}

Rear Porch: The rear porch was an open galley spanning the entire breadth of the house (east-west) and extending southward approximately 3.66 meters (12 feet). The brick foundation piers (4) are intermittently spaced and depended on the length of available sill beams, and additional support was provided by interior brick piers placed roughly parallel to one another and perpendicular to the alignment of the exterior house piers. Renovations probably added later include two shedroom enclosures. The eastern portion (thought to be additional bedroom accommodations) probably measured $3.355 \times 3.66$ meters ( $11 \times 12$ feet) and the western portion (thought to be a formal dining 
room) measured $3.05 \times 3.66$ meters ( $10 \times 12$ feet). Two brick foundation piers were added between the southwest corner pier and the west central pier (of the porch); these could have been intended as supplemental support for the enclosure of the west end of the porch, or they could possibly represent the supports for an entry to the formal dining room. A break in the house roof from a steep 45 degrees is accountable for the porch (and later enclosures) being "attached to the main roof at the eaves," thus, "the shed roof projects at a lesser pitch, forming a break in the profile" (Jordan 1978: 137) (Table 7).

Flush with the back porch, a series of approximately two to three bricks coursework possibly serves for drainage/ runoff purposes (Table 7 and Fig. 3).

Although the reconstruction presented may be that of the Home as originally built by Sam Houston, the association cannot be made with certainty. At present the brick architectural features uncovered at the site which are the basis of the reconstruction can only be assigned to the period before 1878. Assignment of the construction to the time between 1847 when Houston bought the site property and 1878 is based on two sets of data:

(1) All of the features recorded are composed of hand-molded, low-fired brick which date from the middle of the nineteenth century and are clearly an integral part of a single construction episode or a series of closely spaced building episodes. The distribution of these features approximates the perimeters of the existing house, and artifacts associated with the features, although few in number, consistently date to the middle of the nineteenth century. 
(2) The construction episode(s) undertaken during the Smedes occupation of the site, which consists of a number of additions east of the main house structure, was well-documented during the 1979 investigations by Clark. The foundation supports used during this period are composed of roughly shaped sandstone blocks and poured concrete rather than brick.

Many aspects of the above reconstruction indicate a Chesapeake-Tidewater (Virginia) mode of architecture popular in Eastern Texas log buildings (Jordan 1978). Houston supposedly modeled "The Woodlands" after his birthplace, The Timber Ridge Plantation (Tidewater, Virginia) and monetarily speaking was very capable of building a home of this size and nature. He placed specific importance on his "bang-up place" (Bell, Klein and Hoffman 1975) with particular inferences made toward the love of "the open galley Porch" of his childhood home (James 1975).

Assessment of Restoration Impact

An important aspect of the present investigations was to insure that subsurface architectural features and intact midden deposits existing at the site! would not be adversely affected by ongoing restoration activities. If these activities are monitored, especially in the identified areas of archeological sensitivity, and caution continues to be exercised by the restoration architects and construction crews, the significant components of "The Woodlands" will not be adversely affected. 
TABLE 7

METRIC DATA FOR REAR PORCH

Rear Porch:

SE corner of porch to SE corner of house

$3.75 \mathrm{~m}\left(12^{\prime} 4^{\prime \prime}\right)$

SE corner of porch to center of fireplace

$6.75 \mathrm{~m}\left(22^{\prime} 4^{\prime \prime}\right)$

Alignment Piers:

SW corner pier to west central pier

$5.30 \mathrm{~m}\left(17^{\prime} 3^{\prime \prime}\right)$

SW corner pier to east central pier

$11.3 \mathrm{~m}\left(37^{\prime}\right)$

SW corner pier to SE corner pier

$15.2 \mathrm{~m}\left(49^{\prime} 4^{\prime \prime}\right)$

West shed enclosure

$3.050 \times 3.660 \mathrm{~m}$ $\left(10 \times 12^{\prime}\right)$

East shed enclosure

$3.355 \times 3.660 \mathrm{~m}$ $\left(11 \times 12^{\prime}\right)$

West central (exterior) pier to west interior pier

$1.22 \mathrm{~m}\left(4^{\prime} 0^{\prime \prime}\right)$

Feature 3 - West interior pier

Feature 4 - East interior displaced pier

Feature 12 - SW corner pier

Feature 13 - SE corner and east central (exterior) piers

Feature 15 - added support pier; SE corner of west enclosure

Feature 16 - West central (exterior) pier

Brick Coursework - Drainage/Runoff:

Clark's findings in SW and SE corner areas - south of rear porch 2-3 courses of hand-molded bricks; specifically:

Test Pits 33, 39, 41, 43 - SW

Test Pits 22, 26, 28, 29, 31 - SE

Feature 18 - SE

Feature 20 - SW 
All the features exposed during the current investigations will be covered with plastic sheeting; the test units containing the features will be filled with sand and will then be compacted by tamping. These precautions will sufficiently cushion the features so that they will be preserved intact.

Borrowed fill will be placed in the area of the rear porch of the house to level the present ground surface prior to any major construction. The fill, which will add as much as 40-50 centimeters to the existing soil covering the archeological deposits and features, will act as a buffer during the construction. The placement and leveling of the new surface will not involve the use of heavy machinery in archeologically sensitive areas.

The use of jackhammers to break up and remove the modern brick walkways will not disturb identified significant or sensitive historic remains.

It should be noted that, while the 1979 and the 1980 archeological investigations have provided substantial data regarding the history of the Houston Home, there are many problems yet to be solved at the site. The investigation of outbuildings associated with the 1847-1878 occupations was limited to identifying the general location of the presumed original detached kitchen (Clark 1980: 49, 52 and 54). No attempt was made to locate other outbuildings which are presumed to have existed during that period. Features 18, 20 and 21, which were noted south of the house and rear porch, have not been satisfactorily explained. The entire area south of the house and extending to 19th Street is considered to be archeologically sensitive since that area should contain the features and artifacts necessary to interpret the potential activities 
which may have been carried out in that area of the site. The area east of the house is equally sensitive since the full extent of the Smedes additions has not been explored or recorded. The area southeast of the house and now covered by the representative detached kitchen at least partially coincides with the original detached kitchen location and should not be disturbed without extensive prior archeological investigations. Further, the original location of the Law Office has yet to be documented even though the present location of that structure is thought to be at least representative if not relatively close to the original positioning.

The cautions made by Clark (1980: 56-57) regarding any future subsurface alterations in the sensitive areas of the site are supported here, and the site's custodians are reminded that well-intentioned activities can result in the disruption or destruction of evidence crucial to the understanding and interpretation of events associated with Houston's occupation of "The Woodlands." The history and lore of Sam Houston belongs to all the people of the State of Texas and should be maintained with care. 
Bell, Wayne, John Klein and David Hoffman

1975 Preservation and Development Plan for Sam Houston Memorial Museum. Report prepared for Sam Houston State University by Bell, Klein and Hoffman, Architects and Restoration Consultants, Austin.

Boger, Louise Ade

1971 The Dictionary of World Pottery and Porcelain. Charles Scribner \& Sons, New York.

Brann, Donald R.

1965 How to Buizd and Enclose a Porch. Directions Simplified, Inc., Briarcliff Manor, New York.

Bullock, Orin M.

1966 The Restoration Manual. Silvermine Publishers, Inc., Norwalk, Connecticut.

Clark, John W., Jr.

1980 The Woodlands: Archeological Investigations at the Sam Houston Home, Huntsville, Walker County, Texas. Prewitt and Associates, Inc. Reports of Investigations, Number 4, Austin.

James, Marquis

1975 The Raven: A Biography of Sam Houston. Mockingbird Books, Atlanta.

Jordan, Terry G.

1978 Texas Log Buildings, A Folk Architecture. University of Texas Press, Austin.

Murray Moore Surveyors

1935 Water Resource Planning submitted to the City of Huntsville, Walker County, Texas. 